\title{
Tourmaline and Rutile as Indicators of a Magmatic-hydrothermal Origin for Tourmalinite Layers in the São José do Barreiro Area, NE Ribeira Belt, Southern Brazil
}

\author{
Turmalina e Rutilo como Indicadores da Origem Magmática-hidrotermal dos \\ Níveis de Turmalinito de São José do Barreiro, Cinturão Ribeira, Sudeste do Brasil \\ Gianna Maria Garda' (giagarda@usp.br),Paulo Beljavskis' (beljavskis@terra.com.br), \\ Liz Zanchetta D'Agostino² (lizanca@gmail.com), Michael Wiedenbeck ${ }^{3}$ (michawi@gfz-potsdam.de) \\ 'Departamento de Mineralogia e Geotectônica - Instituto de Geociências - USP \\ R. do Lago 562, CEP 05508-080, São Paulo, SP, BR \\ ${ }^{2}$ Laboratório de Caracterização Tecnológica - POLI/USP, São Paulo, SP, BR \\ ${ }^{3}$ Helmholtz Centre Potsdam - GFZ German Research Centre for Geosciences, Potsdam, DE
}

Received 04 May 2010; accepted 04 August 2010

\begin{abstract}
Tourmalines from tourmaline-rich layers intercalated with schists of the Rio Una Unit of the Embu Complex and from coarse-grained tourmalinite layers associated with quartzite from São José do Barreiro and Formoso (Central Ribeira Belt, São Paulo State, Brazil) were analyzed for major, trace- and rare-earth elements and boron stable isotopes. Two main phases of tourmaline formation were identified by mineral chemistry. The tourmalines from the schist-hosted tourmaline layers are characterized by relatively low $\mathrm{MgO}$ (from 4.7 to $6.5 \%$ ), $\mathrm{Na}_{2} \mathrm{O}$ (1.5 to $2.1 \%$ ) and $\mathrm{CaO}$ (from 0.2 to $1.1 \%$ ) contents and high $\mathrm{Al}_{2} \mathrm{O}_{3}$ (from 32 to $35 \%$ ) and $\mathrm{FeO}$ (from 6.7 to $9.0 \%$ ) contents, and also by two (REE) CN $_{\mathrm{CN}}$ patterns, one represented by $(\mathrm{La} / \mathrm{Yb})_{\mathrm{CN}}$ from 2.7 to 4.3 and positive Eu anomalies, and the other by $(\mathrm{La} / \mathrm{Yb})_{\mathrm{CN}}$ from 0.2 to 0.3 and practically no Eu anomaly. The variations in major-element contents reflect the composition of the rock being metamorphosed and in which tourmaline is crystallizing, whereas the $(\mathrm{REE})_{\mathrm{CN}}$ patterns indicate the evolution of the metamorphic fluid in face of changing metamorphic conditions. The tourmaline of the tourmalinite layers intercalated in quartzite is characterized by relatively high $\mathrm{Al}_{2} \mathrm{O}_{3}$ (from 32.3 to $33.92 \%$ ), $\mathrm{FeO}$ (from 6.54 to $7.3 \%$ ) and $\mathrm{Na}_{2} \mathrm{O}$ (from 1.8 to $2.1 \%$ ) contents and very low total REE (3.5 $\mathrm{ppm})$ contents, in particular of HREE. The (REE) ${ }_{\mathrm{CN}}$ pattern for this tourmaline is characterized by a positive Eu anomaly, indicating a high fluid/rock ratio. The $\delta^{11} \mathrm{~B}$ values for this tourmaline fall in the -12.3 and $-13.9 \%$ interval. On the other hand, the tourmaline of a massive tourmalinite also associated with quartzite has the highest $\mathrm{MgO}$ (from 7.3 to $9.7 \%$ ), $\mathrm{CaO}$ (from 0.8 to $2.5 \%$ ), F, Th, U, Hf, Zr, Y, Sr and total REE (305 ppm) contents and the lowest $\mathrm{Al}_{2} \mathrm{O}_{3}$ (from 28.6 to $31.8 \%$ ) and $\mathrm{FeO}$ (from 5.4 to $8.3 \%$ ) contents, when compared to the other tourmalines analyzed. Differing from all other (REE) $)_{\mathrm{CN}}$ patterns, the one that characterizes this tourmaline is LREE-enriched $\left[(\mathrm{La} / \mathrm{Yb})_{\mathrm{CN}}=5.8\right]$ and shows a slightly negative Eu anomaly. Negative $\delta^{11} \mathrm{~B}$ values in the -13.9 and $-15.8 \%$ interval indicate, as the other interval, filiation with S-type granite magmatismhydrothermalism. The massive tourmalinite also contains zircon, scheelite, and monazite as accessory minerals and relatively abundant (green and red) rutile. The green rutile is enriched in $\mathrm{Nb}, \mathrm{Al}, \mathrm{Fe}$ and $\mathrm{Sn}$ when compared to the red rutile, which is $\mathrm{Cr}$ rich. The differences in composition observed in the tourmaline and rutile of the massive tourmalinite indicate the involvement of magmatic-hydrothermal fluids with metamorphic fluids from which tourmaline and other minerals crystallized. The syncollisional, S-type São José do Barreiro Granite is the possible source for the magmatic-hydrothermal fluids.
\end{abstract}

Keywords: Tourmalinites; Rutile; São José do Barreiro Granite; REE in tourmaline.

\section{RESUMO}

Turmalinas de níveis ricos em turmalina intercalados com os xistos da Unidade Rio Una do Complexo Embu e de turmalinitos grossos associados a quartzito da região de São José do Barreiro e Formoso (Cinturão Ribeira, SP, Brasil) foram analisadas para elementos maiores, traço e terras raras e isótopos estáveis de boro. Duas fases principais de formação de 
turmalina foram identificadas pela química mineral. A primeira fase, que corresponde a níveis ricos em turmalina intercalados em xistos, caracteriza-se pelos teores relativamente baixos de $\mathrm{MgO}$ (entre 4,7 e 6,5\%), $\mathrm{Na}_{2} \mathrm{O}(1,5$ e 2,1\%) e $\mathrm{CaO}($ entre 0,2 e $1,1 \%)$ e altos de $\mathrm{Al}_{2} \mathrm{O}_{3}$ (entre 32 e 35\%) e $\mathrm{FeO}$ (entre 6,7 e 9,0\%). Dois padrões de elementos terras raras (normalizados para o condrito C1) são representados respectivamente por razões $(\mathrm{La} / \mathrm{Yb})_{\mathrm{NC}}$ de 2,7 a 4,3 e anomalias positivas de Eu e razões $(\mathrm{La} / \mathrm{Yb})_{\mathrm{NC}}$ de 0,2 a 0,3 e anomalias de Eu praticamente ausentes. As variações nos teores de elementos maiores refletem as composições da rocha hospedeira que está sendo metamorfizada e na qual a turmalina está se cristalizando, ao passo que os padrões de ETR indicam a evolução do fluido metamórfico face às condições de metamorfismo. A segunda fase de turmalina, que compõe níveis de turmalinito intercalados com quartzito, caracteriza-se pelos teores relativamente elevados de $\mathrm{Al}_{2} \mathrm{O}_{3}$ (entre 32,3 e 33,92\%), FeO (entre 6,54 e 7,3\%) e $\mathrm{Na}_{2} \mathrm{O}$ (entre 1,8 e $2,1 \%$ ) e teores muito baixos de ERT total (3,5 ppm), em particular de ETR leves. O padrão de ETR para esta turmalina caracteriza-se pela anomalia positiva de $\mathrm{Eu}$, o que indica alta razão fluido/rocha. Os valores de $\delta^{11} \mathrm{~B}$ obtidos para esta turmalina caem no intervalo entre $-12,3$ e $-13,9 \%$. No extremo oposto, a turmalina do turmalinito maciço, também associado a quartzito, apresenta os teores mais altos de $\mathrm{MgO}$ (entre 7,3 e 9,7\%), $\mathrm{CaO}$ (entre 0,8 e 2,5\%), F, Th, U, Hf, Zr, Y, Sr e ETR total (305 ppm) e os mais baixos de $\mathrm{Al}_{2} \mathrm{O}_{3}\left(\mathrm{entre}^{28,6}\right.$ e $31,8 \%$ ) e $\mathrm{FeO}$ (entre 5,4 e 8,3\%), quando comparada às demais turmalinas analisadas. Diferentemente dos demais padrões de ETR, o que caracteriza esta turmalina é o enriquecimento em ETR leves $\left[(\mathrm{La} / \mathrm{Yb})_{\mathrm{NC}}=5,8\right]$ e leve anomalia negativa de Eu. Valores negativos de $\delta^{11} \mathrm{~B}$ no intervalo entre -13.9 e $-15.8 \%$ indicam, tal qual o anterior, a filiação com magmatismo-hidrotermalismo granítico do tipo $\mathrm{S}$. O turmalinito maciço também contém zircão, scheelita e monazita como minerais acessórios e rutilo (verde e vermelho) abundante. O rutilo verde é mais enriquecido em $\mathrm{Nb}, \mathrm{Al}, \mathrm{Fe}$ e $\mathrm{Sn}$ do que o rutilo vermelho que, por sua vez, é mais rico em $\mathrm{Cr}$. As diferenças nas composições da turmalina e do rutilo do turmalinito maciço indicam o envolvimento de fluidos magmáticos-hidrotermais na evolução dos fluidos metamórficos dos quais turmalina e outros minerais cristalizaram-se. O Granito São José do Barreiro, do tipo S e sin-colisional, é a possível fonte desses fluidos magmáticos-hidrotermais.

Palavras-chave: Turmalinito; Rutilo; Granito São José do Barreiro; ETR em turmalina.

\section{INTRODUCTION}

São José do Barreiro and Formoso are located in the central part of the Neoproterozoic Ribeira Belt, about $260 \mathrm{~km}$ east of São Paulo city. In that hilly area, tourmalinerich layers, which are usually associated with quartzite, are known as saibreiras (UFRJ/CPRM, 2007) and stand out in relief from the surrounding rocks.

Pereira, Ávila and Moura (2001) described tourmalinerich boudins and layers in the region limited by Campos de Cunha, Areias and Formoso, which are hosted by schists of the Rio Una Unit of the Embu Complex (Figure 1). These authors also used the occurrence of tourmalinerich layers to distinguish the Rio Una Unit quartzites from those of the Redenção da Serra Unit (also Embu Complex). In a following exploratory study on the tin potentiality of the Funil and São José do Barreiro granitic bodies, Pereira, Ávila and Neumann (2003) observed a constant association of cassiterite with coarse-grained black tourmaline and quartz in pan mineral concentrates. The coarse-grained tourmaline was genetically related to pegmatitic bodies and to quartz-tourmaline veins. Another type of tourmaline, finer-grained and light brown, was related to the tourmalinite layers that frequently occur in the study area.

Tourmaline is considered a recorder of petrogenetic information (e.g., Henry and Guidotti, 1985; Jolliff, Papike, Laul, 1987; Palmer and Slack, 1989; Slack, 1996; Marchall and Ludwig, 2006; Bortnikov et al., 2008) because it can accommodate a large variety of cations in terms of size and charge in its structure and as a consequence it acquires the geochemical signature of the medium from which it crystallized.

In the saibreiras we also found rutile in considerable quantities. In recent years rutile chemistry and thermometry have been used as a guide to provenance for a variety of geological settings (e.g., Zack, Von Eynatten, Kronz, 2004; Zack, Moraes, Kronz, 2004; Fernández, Schalamuk, Omenetto, 2005; Müller and Halls, 2005; Meinhold et al., 2008; Morton and Chenery, 2009), because rutile is chemically and physically stable and not prone to destruction during the sedimentation cycle.

In order to further investigate the possible genetic relationships between schist-hosted tourmaline-rich layers and the tourmalinite layers in the saibreiras of the São José do Barreiro-Formoso area, a geochemical study was carried out, including major-element, trace-element and boron stable isotope analyses of tourmaline and rutile chemistry.

\section{GEOLOGIC SETTING}

The Ribeira Belt extends for more than 1,400 km along the southeastern coast of Brazil and is the main tectonic unit of the Mantiqueira Province (Hasui and Oliveira, 1984). It resulted from the collision of the São Francisco, Congo and Rio de la Plata cratons during the agglutination of Western Gondwana in the Brasiliano event (e.g., Roig, 
Dantas, Menezes, 2004). The study area is located in the Embu domain of the central Ribeira Belt, delimited from surrounding domains by dextral transcurrent faults (Cubatão and Alto da Fartura Shear Zones), and is partially covered by the Tertiary Resende and Taubaté basins (Figure 1).

The Embu Domain is made up of the metasedimentary rocks of the Embu Complex. The Rio Una and the Redenção da Serra units of the Embu Complex are recognized in the study area (Pereira, Ávila, Moura, 2001). The Rio Una Unit is composed of fine- to mediumgrained (quartz-muscovite, biotite-muscovite, sillimanite and quartzo-feldspatic) schists, which are intercalated with quartzite, tourmalinite layers and amphibolitic rocks. The Rio Una Unit is in direct contact with the migmatites and garnet-biotite gneisses of the Redenção da Serra Unit to NW and with a number of granites and granitoids of Mesoproterozoic to Cambrian ages (Figure 1).

Pereira, Moura and Bustamante-Junho (2002) identified five magmatic episodes in the central portion of the Ribeira Belt: pre-collisional (630 - $595 \mathrm{Ma})$, syn-collisional $1(605-565 \mathrm{Ma})$, syn-collisional $2(565-540 \mathrm{Ma})$, latecollisional $(540-520 \mathrm{Ma})$ and post-collisional (520 $480 \mathrm{Ma})$. The undeformed Funil Granite $\left(50 \mathrm{~km}^{2}\right)$ crops out northwest of São José do Barreiro and is composed of leucocratic, gray to pinkish, porphyritic and fine-grained

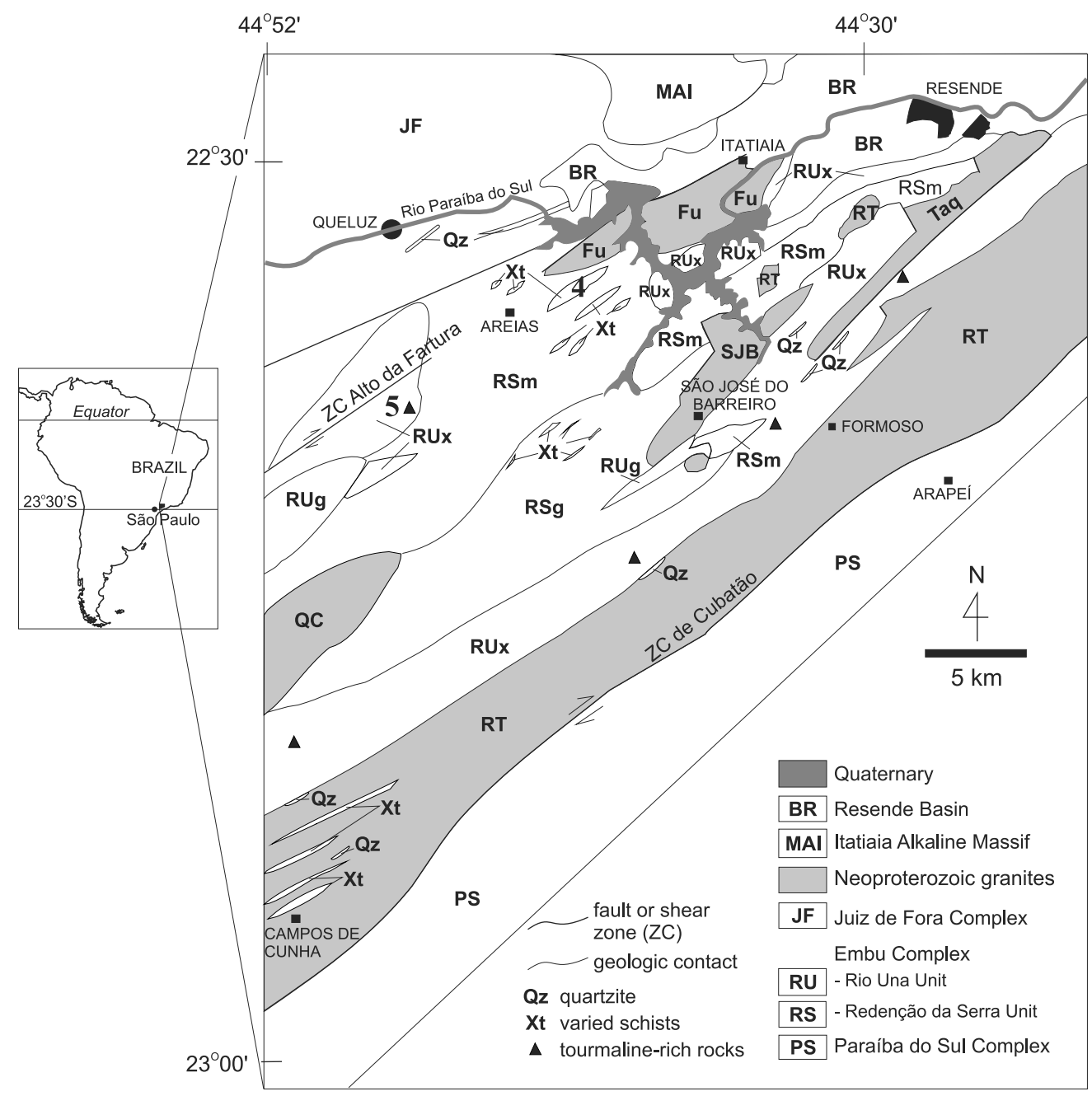

Figure 1. Simplified geologic map of the Queluz-Resende-Campos de Cunha region (mod. after Pereira, Ávila, Moura, 2001). Neoproterozoic granites: RT = Rio Turvo (579 $\pm 6 \mathrm{Ma})$; SJB = São José do Barreiro (603 $\pm 3 \mathrm{Ma}) ; \mathbf{Q C}=$ Quebra-Cangalha; Fu = Funil $(584 \pm 5 \mathrm{Ma}) ; \mathbf{T a q}=$ Taquaral $(605 \pm 11 \mathrm{Ma})$. Embu Complex, Redenção da Serra Unit: RSg = biotite-garnet gneisses; $\mathbf{R S m}=$ migmatites, augen gneisses, banded gneisses, quartzites; Rio Una Unit: RUx = varied schists with quartzite and tourmalinite intercalations; $\mathbf{R U g}=$ fine biotite gneisses. Points 1, 2, 4, 5 and 8 correspond to tourmalinite layers of the Rio Una Unit sampled by R. M. Pereira and referred to in the text as SRJ. 
equigranular rocks of I-type compositional affinity (Pereira, Moura, Bustamante-Junho, 2002; Pereira, Ávila, Neumann, 2003). The foliated São José do Barreiro Granite $\left(45 \mathrm{~km}^{2}\right)$ is a dark-gray, medium-grained, inequigranular to porphyritic biotite granite characterized as S-type and showing a strong REE fractionation. Both granites are related to the syncollisional 1 episode of Pereira, Moura and BustamanteJunho (2002): the São José do Barreiro Granite (603 \pm 3 Ma) formed prior to the regional metamorphism, whereas the Funil Granite $(584 \pm 5 \mathrm{Ma})$ is coeval with the metamorphic peak (579 Ma).

\section{TOURMALINES}

\section{Materials and methods}

Five samples of tourmaline separates corresponding to the Rio Una Unit schist-hosted tourmaline-rich layers (Figure 1) were kindly donated for this study by Dr. Ronaldo Mello Pereira (Universidade do Estado do Rio de Janeiro). The crystals were mounted in epoxy resin and polished for microprobe analysis. The five samples are referred to in the text as SRJ-01, SRJ-02, SRJ-04, SRJ-05 and SRJ-08.

In addition to the tourmaline separates, whole-rock samples from a schist-hosted tourmaline-rich layer and tourmalinites intercalated in saibreira were also analyzed. Sample BM2 was collected close to point 8 in Figure 1 and is from a garnet-biotite schist containing color-zoned, poikiloblastic tourmaline (Figure 2A). Samples SJB-3A and SBJ-3B were collected close to the Camponesa Farm, $5 \mathrm{~km}$ east of São José do Barreiro (point 2 of Figure 1). Sample SJB-3A is from a thin tourmalinite layer intercalated in quartzite (saibreira) and is composed of color-zoned tourmaline (Figure 2B). Sample SJB-3B is from a massive tourmalinite formed by coarse-grained, irregularly zoned tourmaline (Figure 2C). Rutile is also abundant in this sample and will be further analyzed in more detail. Polished thin sections of samples BM2, SJB-3A and SJB-3B were prepared for electron microprobe and secondary ion mass spectrometry analyses.

The five SRJ samples and tourmaline separates from SJB-3A and SJB-3B were analyzed by inductivelycoupled plasma mass spectrometry for trace-element and REE concentrations.

The polished thin sections and epoxy mounts of the SRJ tourmaline separates were coated with carbon for the electron microprobe analysis (EMPA). The WDS analyses of tourmaline were performed with the JEOL Superprobe JXA-8600 at the Microprobe Laboratory of the Instituto de Geociências (São Paulo University). Operating conditions were: beam diameter $1-2 \mu \mathrm{m}$, beam current $15 \mathrm{nA}$ and
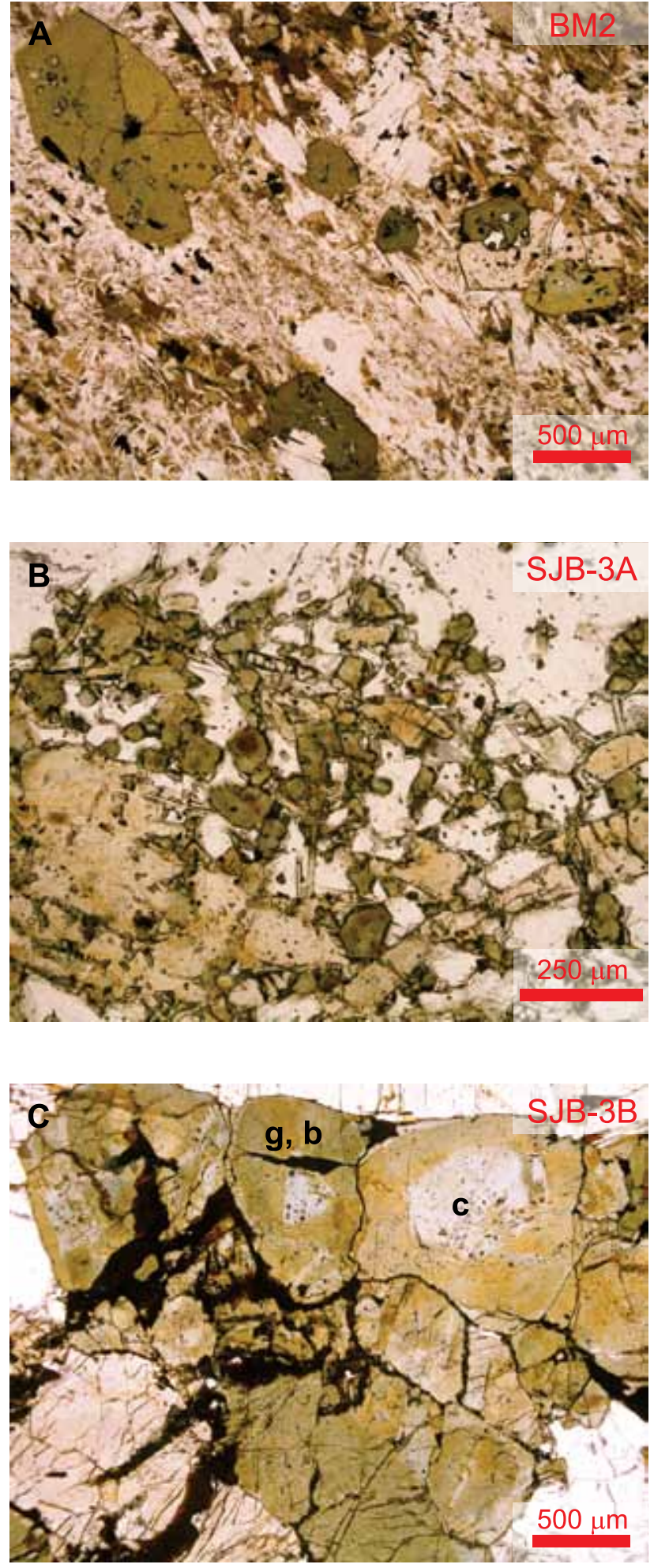

Figure 2. Photomicrographs (plane-polarized light) of colored-zoned tourmalines from samples BM2, SJB-3A and SJB-3B. Gray (c), green (g) and brown (b) zones are signaled on a SJB-3B tourmaline crystal. 
acceleration voltage $15 \mathrm{kV}$. Standards, element lines and counting times were: wollastonite $(\mathrm{Si} \mathrm{K} \alpha)$ : $5-20 \mathrm{~s}$; rutile (Ti $\mathrm{K} \alpha): 10$ - $30 \mathrm{~s}$; hornblende: $(\mathrm{Al} \mathrm{K \alpha}): 10$ - $20 \mathrm{~s}$; olivine (Fe $\mathrm{K} \alpha): 5$ - 20 s; $\mathrm{Cr}_{2} \mathrm{O}_{3}(\mathrm{Cr} \mathrm{K} \alpha): 50$ s; olivine $(\mathrm{Mn} \mathrm{K} \alpha) 20$ - 30 s; diopside (Mg K $\alpha): 20$ - 30 s; wollastonite $(\mathrm{Ca} \mathrm{K \alpha}): 10$ s;

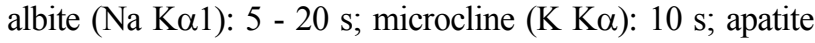
A408 (F K $\alpha)$ : 10 s; chloroapatite CLAP $(\mathrm{Cl} \mathrm{K \alpha}): 10 \mathrm{~s}$.

The inductively-coupled plasma mass spectrometry (ICP-MS) analyses of the five SRJ and SJB-3A and SJB-3B tourmaline separates were conducted on sample solutions at the Chemistry Laboratory of Instituto de Geociencias (São Paulo University) equipped with a Perkin Elmer ELAN 6100 DRC mass spectrometer, using a routine adapted from Navarro (2004). Besides REE, Rb, Sr, Y, Zr, $\mathrm{Nb}, \mathrm{Cs}, \mathrm{Ba}, \mathrm{Hf}, \mathrm{Pb}$, Th and $\mathrm{U}$ were analyzed.

The boron isotopic composition of tourmaline was determined with a Cameca ims-6f instrument at GeoForschungZentrum in Potsdam (Germany) using methods described in detail by Garda et al. (2009). This study was part of the project: "Isotopia do boro em turmalinitos e rochas ricas em turmalina e veios de quartzo do Anticlinal de Mariana (Minas Gerais) e Cinturão Ribeira (São Paulo), SE do Brasil", financed by FAPESP (Proc. 2007/53895-4). The polished thin sections of samples SJB-3A and SJB-3B used for microprobe analysis were prepared for secondary ion mass spectrometry (SIMS) analyses by light polishing with 1 micron alumina and distilled water to remove the carbon, then cleaning in an ultrasonic ethanol bath and coating with a $\sim 35 \mathrm{~nm}$-thick high-purity gold layer. SIMS analyses employed a primary ${ }^{16} \mathrm{O}^{-}$beam at nominal $12.5 \mathrm{kV}$ and $0.8 \mathrm{nA}$ focused to about $15 \mu \mathrm{m}$ diameter on the sample surface. Instrumental mass fractionation (IMF) and analytical quality were determined by means of the tourmaline reference materials dravite (HS \#108796), elbaite (HS \#98144) and schorl (HS \#112566) from the Harvard Mineralogical Museum (Dyar et al., $2001)$, resulting in an external repeatability of $1.7 \%$ o $(1 \sigma)$. The corrected ${ }^{11} \mathrm{~B} /{ }^{10} \mathrm{~B}$ ratios are expressed in the standard delta notation relative to NIST SRM-951 using the value ${ }^{11} \mathrm{~B} /{ }^{10} \mathrm{~B}=4.04362$ (Catanzaro et al., 1970).

\section{Chemical composition of tourmalines}

\section{Major elements by EMPA}

Tourmalines from samples SRJ mounted in epoxy resin and BM2, SJB-3A and SJB-3B polished thin sections were analyzed for major elements and $\mathrm{F}$. As shown in Table $1, \mathrm{Cr}_{2} \mathrm{O}_{3}$ and $\mathrm{Cl}$ were also analyzed, resulting in average 0.03 wt. $\% \mathrm{Cr}_{2} \mathrm{O}_{3}$ and 0.004 wt.\% $\mathrm{Cl}$ contents, which are close to the electron microprobe detection limits and therefore negligible.
In Figures 3 and 4 the chemical compositions of tourmaline are represented separately for the collection of samples labelled SRJ and for BM2, SJB-3A and SJB-3B. For comparison, the fields defined by SRJ tourmaline compositions are represented in both figures.

Figure 3A reproduces Henry and Guidotti (1985) AlFe-Mg diagram and shows that SRJ-01, SRJ-04, SRJ-05 and SRJ-08 plot in field 4 (metapelites and metapsammites coexisting with an Al-saturating phase), which is in agreement with the whole-rock composition of the Rio Una Unit schists. On the other hand, SRJ-02 plots in field 5 (metapelites and metapsammites not coexisting with an Al-saturating phase).

Although all SRJ tourmaline compositions fall intermediate to the schorl-dravite series, differences in composition are observed when major element contents are plotted against $\mathrm{Mg} \#[\mathrm{Mg} \#=\mathrm{Mg} /(\mathrm{Mg}+\mathrm{Fe})$, atomic proportions]. Sample SRJ-02 (average Mg\# $=0.70$ ) differs from the other SRJ tourmalines $(0.49<$ average $\mathrm{Mg} \#<$ $0.61)$ by virtue of its higher $\mathrm{SiO}_{2}$ and $\mathrm{Na}_{2} \mathrm{O}$ contents and lower $\mathrm{Al}_{2} \mathrm{O}_{3}$ and $\mathrm{FeO}$ contents (Table 1 and Figure 4).

The BM2 tourmalines (average $\mathrm{Mg} \#=0.59$ ) plot in the fields defined by SRJ-01, SRJ-04, SRJ-05 and SRJ08 both in Figures 3 and 4, but relative to those, BM-2 has lower $\mathrm{SiO}_{2}$ and higher $\mathrm{Al}_{2} \mathrm{O}_{3}$ and $\mathrm{FeO}$ contents. Samples SJB-3A (average $\mathrm{Mg} \#=0.64$ ) and SJB-3B (average Mg\# $=0.72$ ) plot close to the fields defined by SRJ-02. Part of SJB-3B analyses plot in field 5 of Henry and Guidotti (1985) diagram (Figure 3B) and another part in field 6 $\left(\mathrm{Fe}^{3+}\right.$-rich quartz-tourmaline rocks, calc-silicate rocks, and metapelites).

Compositional variations in SJB-3B tourmalines are much wider than for the other samples (MgO: 7.5 10 wt.\%; $\mathrm{Al}_{2} \mathrm{O}_{3}: 28.5$ - 32.8 wt.\%; $\mathrm{FeO}: 5.1$ - 6.0 wt.\%; $\mathrm{CaO}: 0.5-3$ wt.\%, and $\mathrm{Na}_{2} \mathrm{O}: 1.3-2.4$ wt.\%), some of the compositions tending to the Ca-rich end-member uvite $\left[\mathrm{Ca}\left(\mathrm{Mg}, \mathrm{Fe}^{2+}\right)_{3} \mathrm{MgAl}_{5}(\mathrm{OH})_{3} \mathrm{~F}\left(\mathrm{BO}_{3}\right)_{3} \mathrm{Si}_{6} \mathrm{O}_{18}\right]$. In these cases, $\mathrm{F}$ contents are higher, reaching 0.3 wt.\% (Figure $4 \mathrm{~L}$ ). These wide compositional variations also occur within a single crystal. In Figures $3 \mathrm{~B}$ and $4 \mathrm{G}$ to $4 \mathrm{~L}$ the compositions corresponding to green $(\mathrm{g})$, gray $(\mathrm{c})$ and brown (b) zones of an SJB-3B tourmaline crystal (Figure 2) are represented with black triangles. $\mathrm{Al}_{2} \mathrm{O}_{3}, \mathrm{MgO}$ and $\mathrm{CaO}$ contents are higher at the gray zone (c), whereas $\mathrm{FeO}, \mathrm{TiO}_{2}$, and $\mathrm{Na}_{2} \mathrm{O}$ contents are higher at the green (g) and brown (b) zones.

The EMPA results characterize tourmalines according to major-element compositions as follows:

1. tourmaline from schist-hosted tourmaline-rich layers (SRJ-01, SRJ-04, SRJ-05, SRJ-08 and BM2), with Mg\# $<0.65$ and higher $\mathrm{Al}_{2} \mathrm{O}_{3}$ and $\mathrm{FeO}$ contents, lower $\mathrm{Na}_{2} \mathrm{O}$ contents and slightly lower $\mathrm{CaO}$ contents. The SRJ-02 


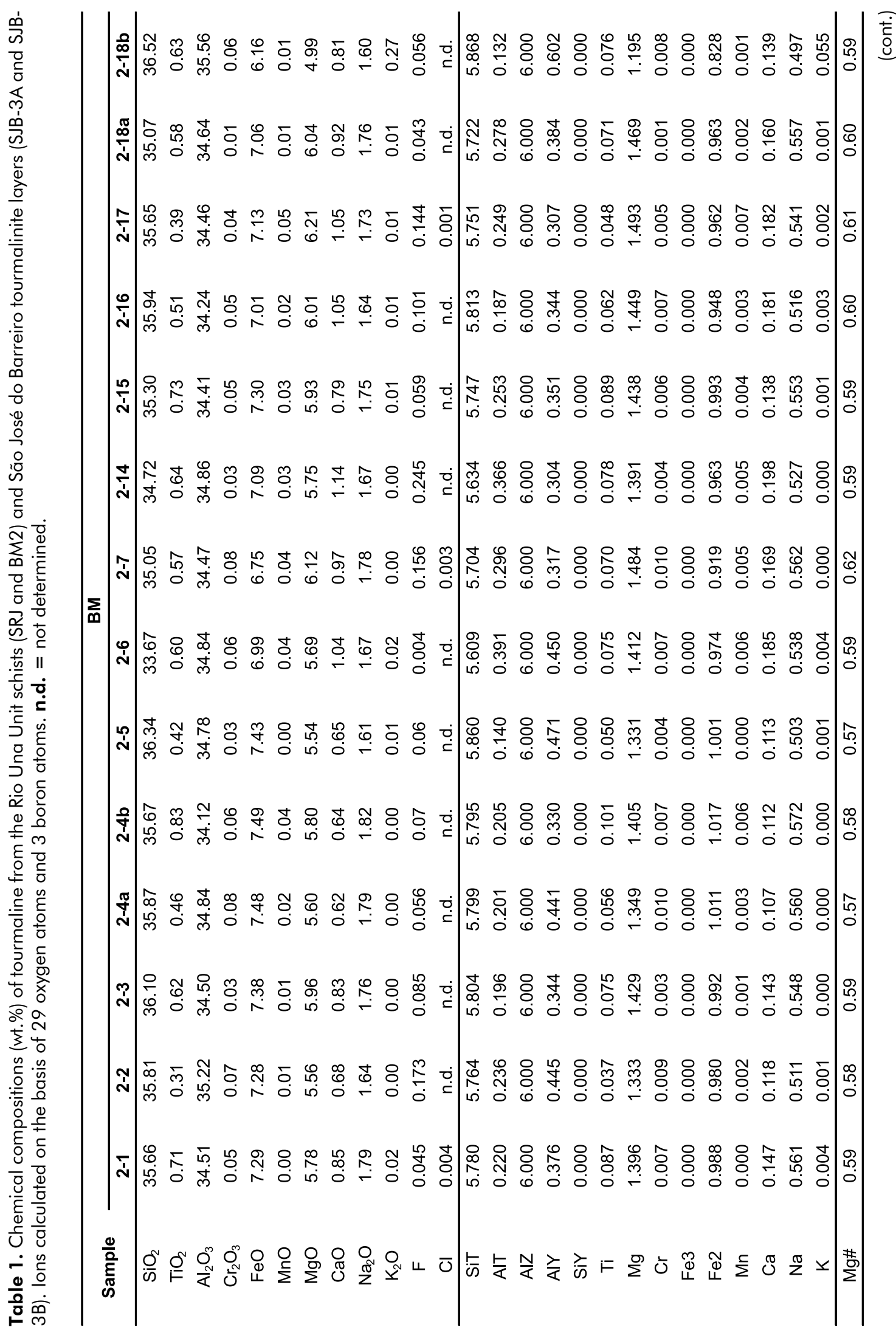




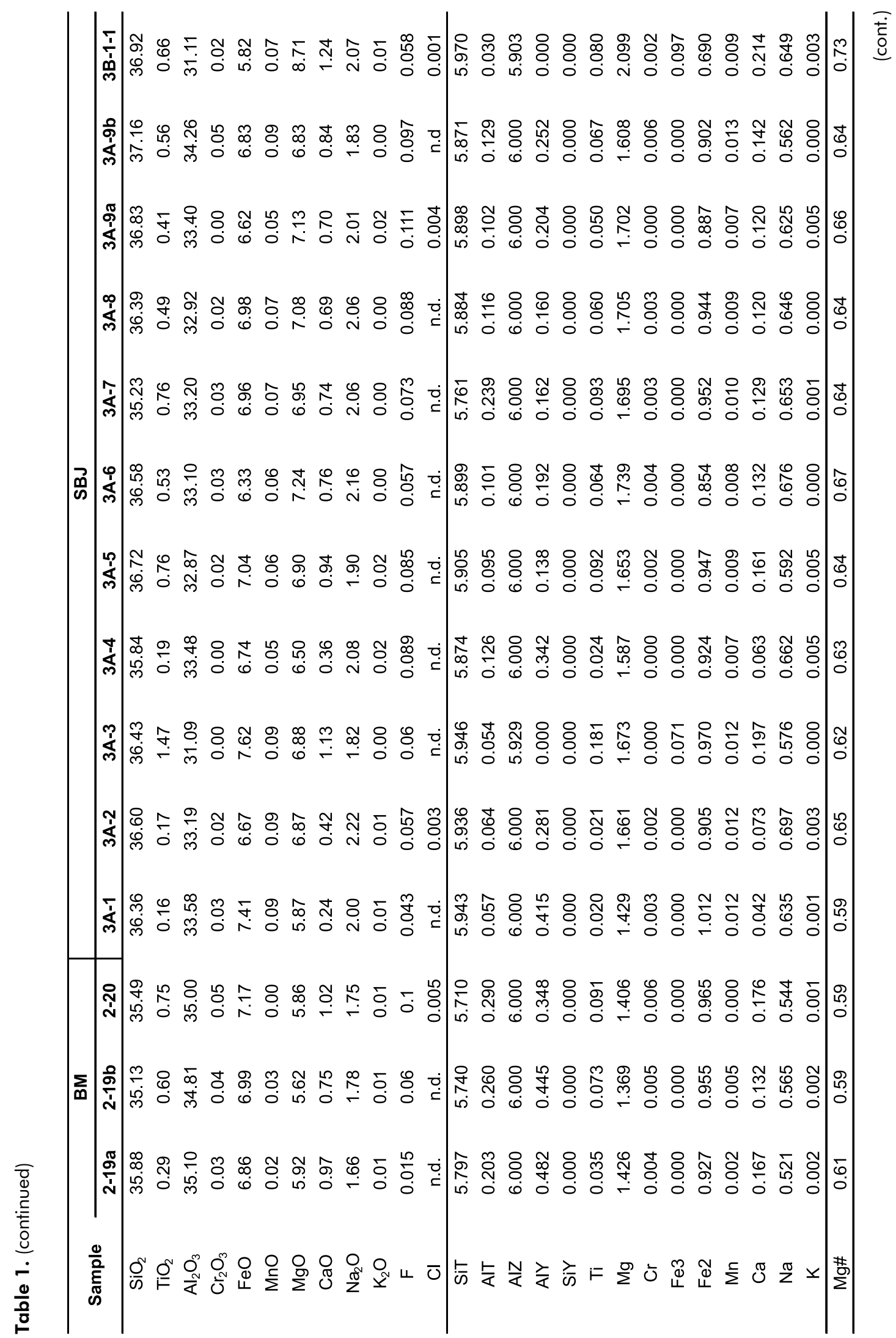




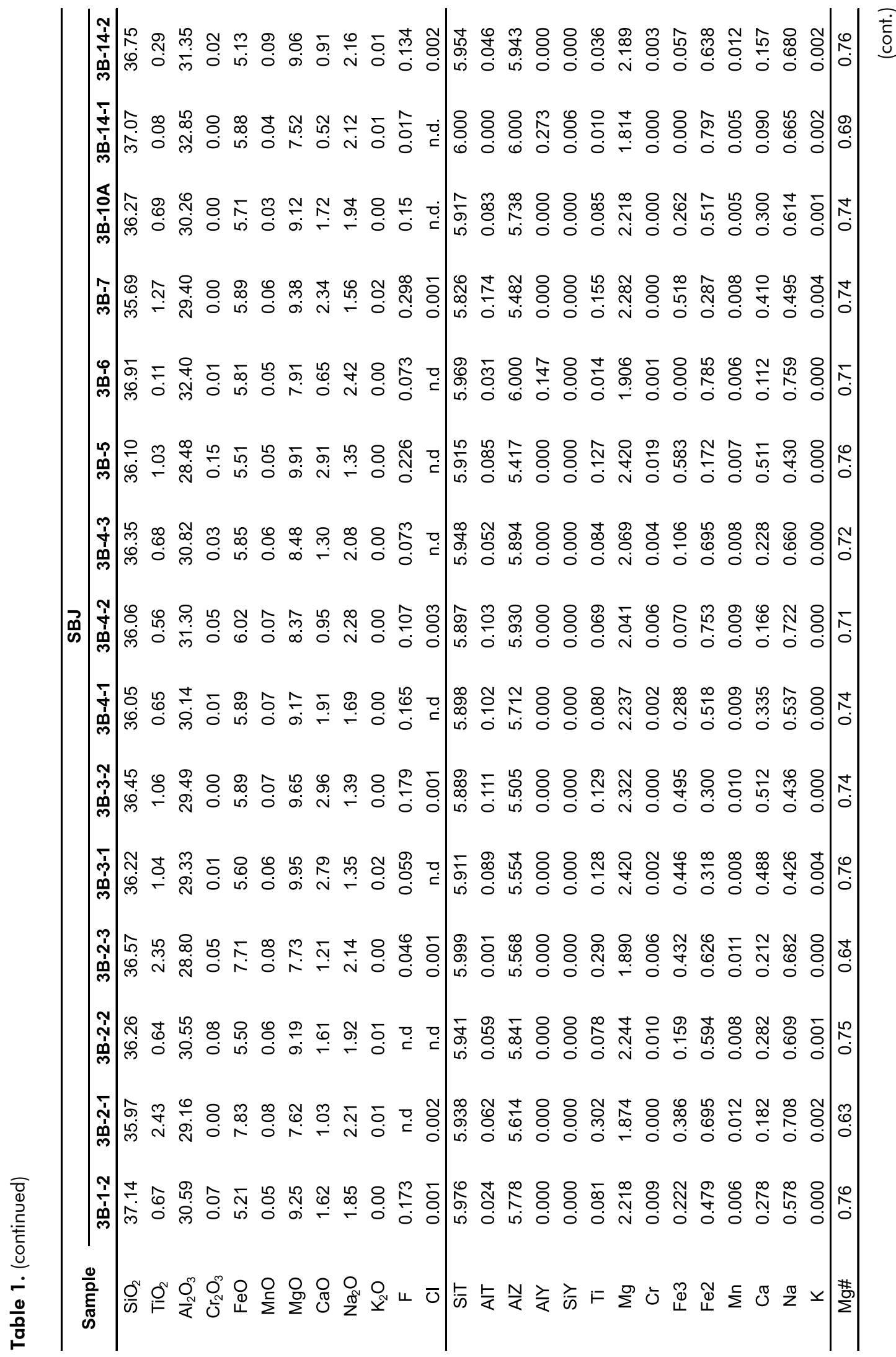




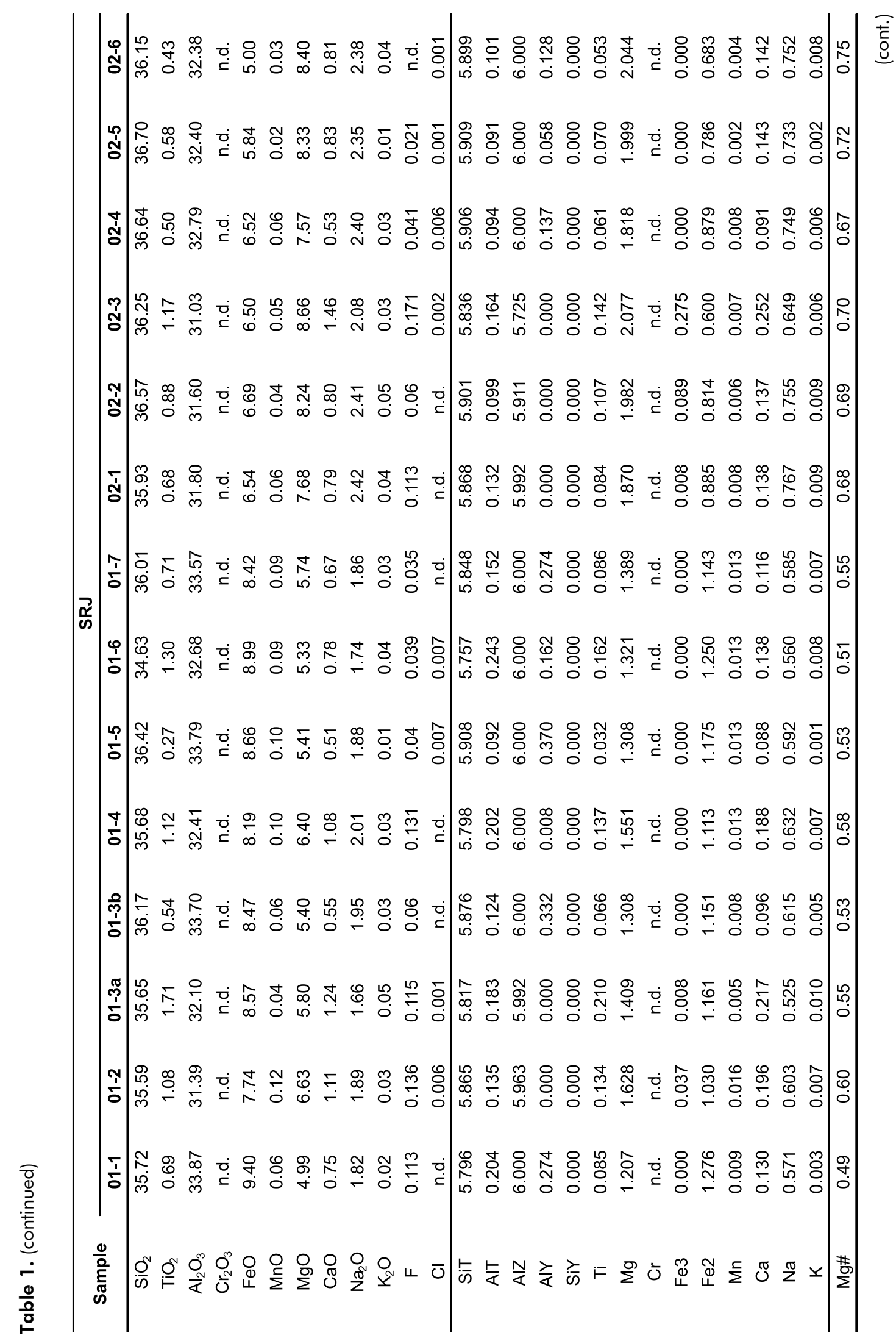




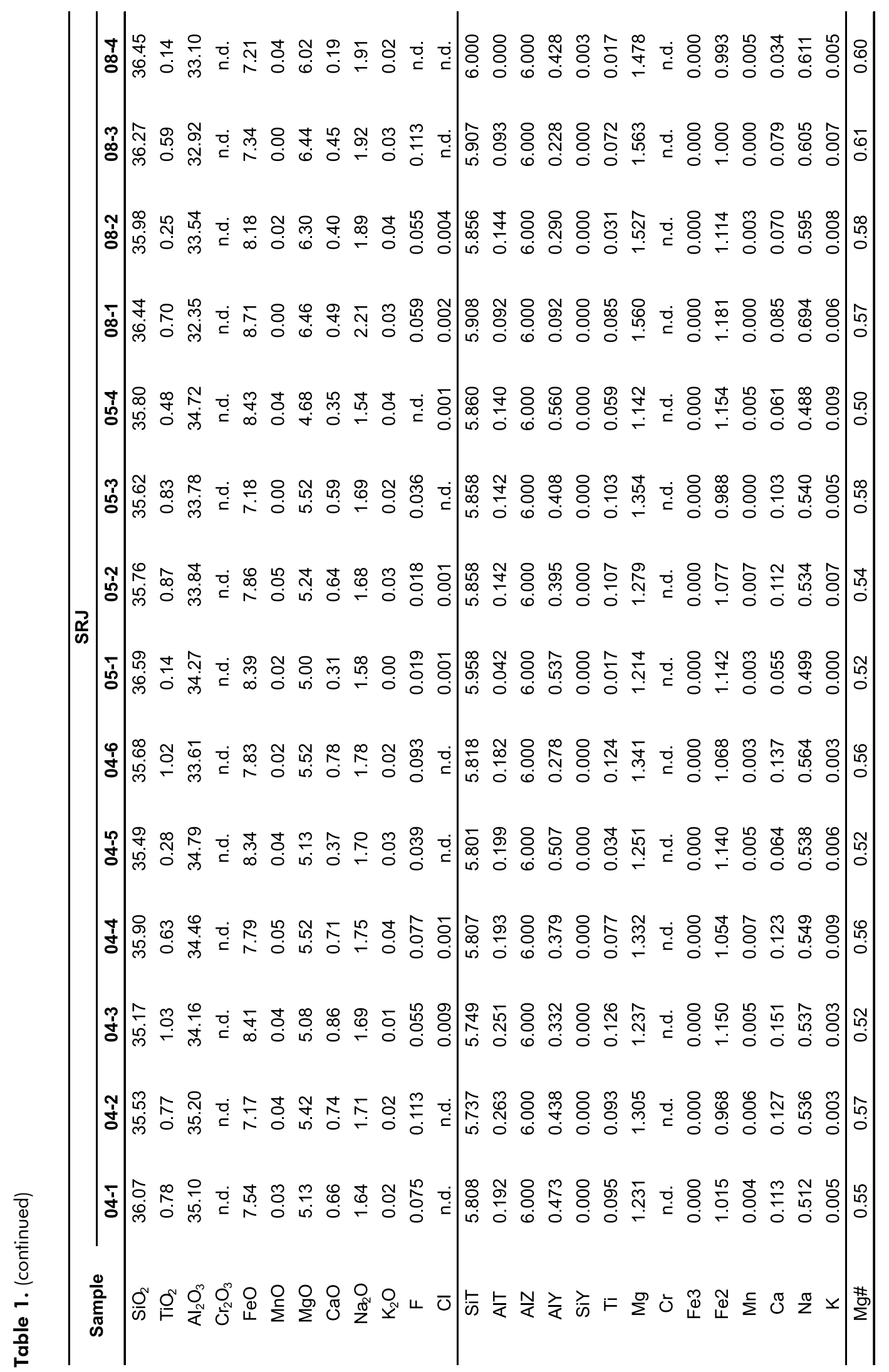


tourmaline, richer in $\mathrm{MgO}$ and $\mathrm{Na}_{2} \mathrm{O}$ and poorer in $\mathrm{Al}_{2} \mathrm{O}_{3}$ and $\mathrm{FeO}$, may reflect the compositional variation of the rock from which it is crystallizing from (e.g., amphibolitic intercalations in schist);

2. tourmaline from SJB-3A, with average $\mathrm{Mg} \#=0.64$, intermediate $\mathrm{Al}_{2} \mathrm{O}_{3}$ and $\mathrm{FeO}$ contents to SRJ and SJB3B tourmaline compositions, and slightly lower $\mathrm{CaO}$ and higher $\mathrm{Na}_{2} \mathrm{O}$ contents relative to SRJ tourmalines;

3. tourmaline from SJB-3B, with Mg\#>0.7, the lowest $\mathrm{Al}_{2} \mathrm{O}_{3}$ and $\mathrm{FeO}$ contents, low $\mathrm{Na}_{2} \mathrm{O}$ contents and high $\mathrm{CaO}$ and $\mathrm{F}$ contents.

\section{REE and trace elements by ICP-MS}

The ICP-MS analyses of REE and trace elements for the SRJ, SJB-3A and SJB-3B tourmaline separates are presented in Table 2. For comparison, $\mathrm{C} 1$ chondritenormalized REE $\left(\mathrm{REE}_{\mathrm{CN}}\right)$ patterns yielded by these tourmalines are represented in Figure 5 together with the results obtained by Pereira (2001) for three samples (whole rock) from the São José do Barreiro Granite.

The total REE contents vary widely from $3.51 \mathrm{ppm}$ (SJB-3A, taking into account that HREE contents are below the ICP-MS detection limits) to $305 \mathrm{ppm}$ (SJB-3B).

The SRJ tourmalines (total REE contents from 8 to $58 \mathrm{ppm})$ define two distinct $\mathrm{REE}_{\mathrm{CN}}$ patterns: pattern 1, characterized by positive Eu anomalies and REE enrichment up to 10 times the chondrite values $\left[(\mathrm{La} / \mathrm{Yb})_{\mathrm{CN}}=2.7-4.1\right]$, and pattern 2, characterized by no evident Eu anomaly and HREE enrichment from 10 to 80 times the chondrite values $\left[(\mathrm{La} / \mathrm{Yb})_{\mathrm{CN}}=0.2-0.3\right]$. Sample SRJ-02 tourmaline, although showing differences in major element composition in relation to the other SRJ tourmalines, yields a very similar $\mathrm{REE}_{\mathrm{CN}}$ pattern to pattern 1 and $(\mathrm{La} / \mathrm{Yb})_{\mathrm{CN}}=4.3$. The $\mathrm{REE}_{\mathrm{CN}}$ pattern for SRJ-04 is also characterized by a positive Eu anomaly, but is $c a$. three times more enriched in REE than those that define pattern 1 and $(\mathrm{La} / \mathrm{Yb})_{\mathrm{CN}}=1.3$.

Bau (1991), analyzing REE mobility during fluidrock interaction related to hydrothermal alteration and metamorphism, takes into account temperature, $\mathrm{pH}, \mathrm{f}_{\mathrm{O} 2}$ and (primary and secondary) mineral/liquid partition coefficients to explain the resulting REE patterns for the altered rock and the fluid. For europium in particular, temperature and $\mathrm{pH}$ can influence the $\mathrm{Eu}^{3+} / \mathrm{Eu}^{2+}$ redox potential. Thus, provided the temperature is high enough, Eu can occur in the divalent oxidation state, even in mildly reducing environments. The change of valence state is accompanied by an increase in ionic radius (HREE $\mathrm{Lu}^{3+}$ $=0.861 \AA<\mathrm{Eu}^{3+}=0.947 \AA<\mathrm{LREE} \mathrm{La}^{3+}=1.032 \AA<$ $\mathrm{Eu}^{2+}=1.17 \AA$ ) and an Eu anomaly will result in the REE pattern, because Eu will behave differently (as a LFSE) from the other REE (HFSE) in that geochemical system. In fluid-rock interactions, the REE pattern of the fluid phase may be governed by: 1) the REE pattern of the rock the fluid is in contact with (e.g., breakdown of primary and/ or precipitation of secondary minerals, causing changes in the mineral/fluid REE partition coefficients); 2) sorption (stronger sorption on mineral or particle surfaces lowers

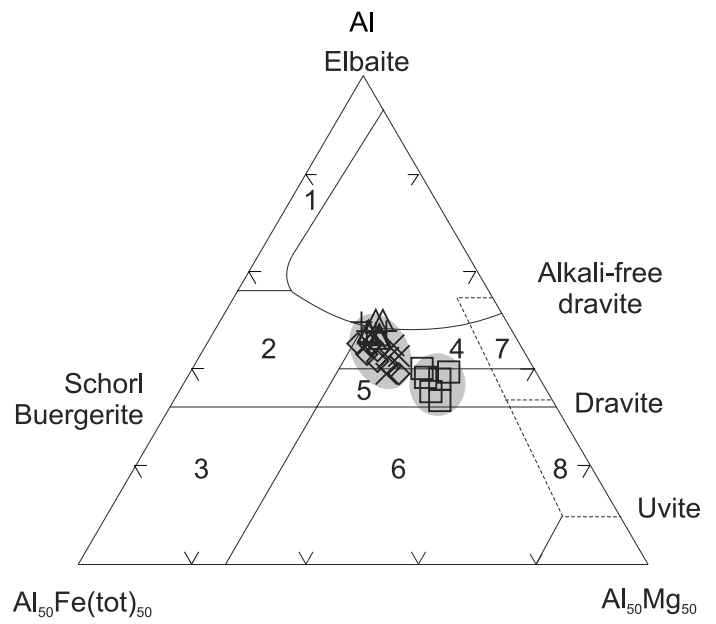

A

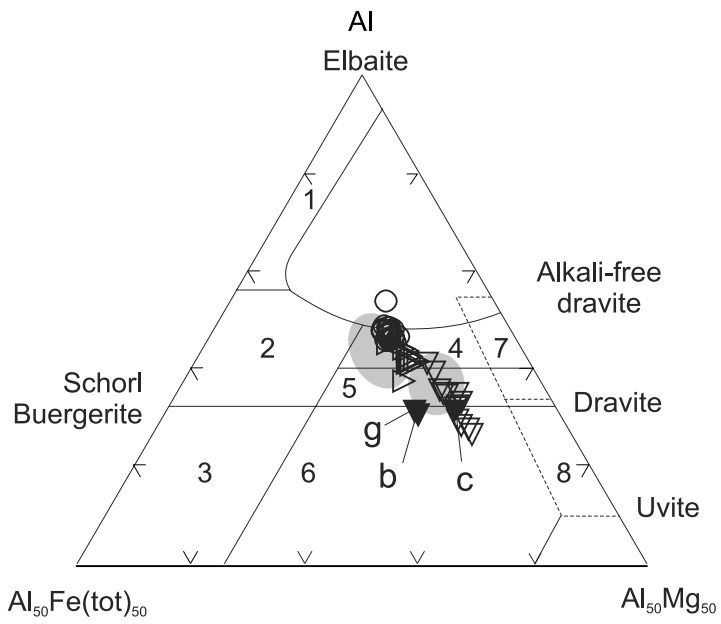

B

Figure 3. Henry and Guidotti (1985) Fe-Al-Mg diagram (atomic proportions). Numbered fields: 1. Li-rich granitoid pegmatites and aplites; 2. Li-poor granitoids and their associated pegmatites and aplites; 3 . Fe ${ }^{3+}$-rich quartz-tourmaline rocks (hydrothermally altered granites); 4. metapelites and metapsammites coexisting with an Al-saturating phase; 5 . metapelites and metapsammites not coexisting with an $\mathrm{Al}$-saturating phase; 6. $\mathrm{Fe}^{3+}$-rich quartz-tourmaline rocks, calc-silicate rocks, and metapelites; 7. low-Ca metautramafics and $\mathrm{Cr}$, V-rich metasediments; 8. metacarbonates and metapyroxenites. Symbols as in Figure 4. 


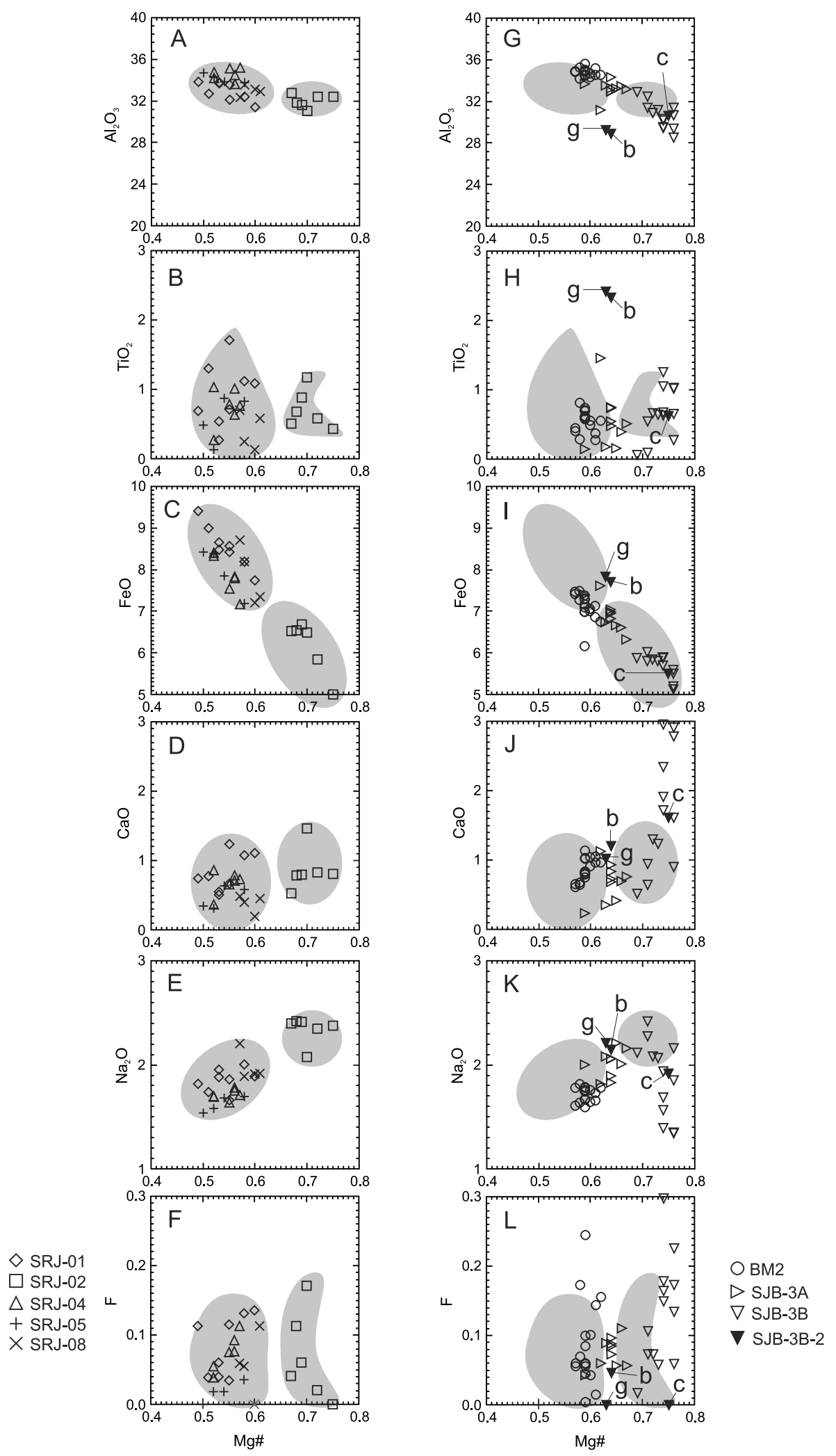

Figure 4. Compositional variations in SRJ (left) and BM2, SJB-3A and SJB-3B (right). Fields in gray represent SRJ analyses. 
Table 2. ICP-MS data for samples SRJ, SJB-3A and SJB-3B (ppm).

\begin{tabular}{|c|c|c|c|c|c|c|c|c|}
\hline & SRJ-01 & SRJ-02 & SRJ-03 & SRJ-04 & SRJ-05 & SRJ-08 & SJB-3A & SJB-3B \\
\hline La & 2.12 & 2.22 & 1.75 & 8.12 & 4.01 & 1.64 & 0.78 & 45.8 \\
\hline $\mathrm{Ce}$ & 3.51 & 3.40 & 2.97 & 16.6 & 6.90 & 3.35 & 1.57 & 117 \\
\hline $\mathrm{Pr}$ & 0.41 & 0.35 & 0.30 & 1.85 & 0.87 & 0.43 & 0.13 & 15.6 \\
\hline $\mathrm{Nd}$ & 1.40 & 1.17 & 0.98 & 6.70 & 3.17 & 1.65 & 0.5 & 67.8 \\
\hline Sm & 0.26 & 0.25 & 0.18 & 1.29 & 1.34 & 0.48 & 0.09 & 15.3 \\
\hline $\mathrm{Eu}$ & 0.62 & 0.32 & 0.56 & 1.40 & 1.05 & 0.44 & 0.17 & 3.22 \\
\hline $\mathrm{Gd}$ & 0.31 & 0.30 & 0.20 & 1.49 & 3.77 & 1.35 & 0.07 & 12.9 \\
\hline $\mathrm{Tb}$ & 0.06 & 0.06 & 0.05 & 0.35 & 1.10 & 0.40 & 0.01 & 1.9 \\
\hline Dy & 0.46 & 0.43 & 0.31 & 3.05 & 9.41 & 3.64 & 0.06 & 10.4 \\
\hline Ho & 0.12 & 0.10 & 0.07 & 0.96 & 2.57 & 1.03 & 0.01 & 2 \\
\hline $\mathrm{Er}$ & 0.41 & 0.31 & 0.23 & 3.62 & 8.75 & 3.31 & 0.04 & 5.51 \\
\hline $\mathrm{Tm}$ & 0.07 & 0.05 & 0.04 & 0.66 & 1.61 & 0.54 & 0.01 & 0.82 \\
\hline $\mathrm{Yb}$ & 0.56 & 0.37 & 0.31 & 4.64 & 11.8 & 3.64 & 0.06 & 5.65 \\
\hline $\mathrm{Lu}$ & 0.10 & 0.06 & 0.06 & 0.77 & 1.86 & 0.56 & 0.01 & 0.85 \\
\hline $\mathrm{Rb}$ & 0.38 & 0.21 & 0.11 & 0.10 & 0.34 & 0.10 & 0.32 & 0.26 \\
\hline $\mathrm{Sr}$ & 201 & 242 & 193 & 114 & 118 & 250 & 203 & 258 \\
\hline $\mathrm{Y}$ & 3.51 & 2.37 & 1.79 & 23.9 & 83.3 & 23.9 & 0.44 & 50.5 \\
\hline $\mathrm{Zr}$ & 130 & 35.1 & 52.7 & 185 & 55.2 & 211 & 16.9 & 778 \\
\hline $\mathrm{Nb}$ & 1.32 & 1.39 & 0.89 & 2.16 & 0.97 & 14.4 & 0.23 & 1.81 \\
\hline Cs & 0.04 & 0.02 & 0.01 & 0.01 & 0.02 & 0.01 & 0.03 & 0.03 \\
\hline $\mathrm{Ba}$ & 5.16 & 5.80 & 2.37 & 2.35 & 4.81 & 1.65 & 2.69 & 2.75 \\
\hline $\mathrm{Hf}$ & 3.93 & 1.34 & 2.15 & 7.05 & 2.74 & 7.93 & 0.53 & 20 \\
\hline $\mathrm{Ta}$ & 0.21 & 0.20 & 0.15 & 0.42 & 0.27 & 1.92 & 0.06 & 0.2 \\
\hline $\mathrm{Pb}$ & 15.8 & 6.89 & 12.1 & 12.5 & 14.2 & 14.4 & 7.07 & 4.68 \\
\hline Th & 0.49 & 0.88 & 0.29 & 1.49 & 1.93 & 1.11 & 0.1 & 6.36 \\
\hline U & 0.37 & 0.24 & 0.26 & 0.46 & 2.55 & 0.61 & 0.07 & 1.76 \\
\hline
\end{tabular}

the amount of a REE in the fluid), and 3) chemical complexation reactions (stronger complexation increases the amount of a REE in the fluid because of the higher solubility of REE complexes compared to uncomplexed REE species).

An example of sorption processes affecting the REE pattern of the fluid phase given by Bau (1991) is the high-temperature $\left(\approx 350{ }^{\circ} \mathrm{C}\right)$ MORB alteration at $\mathrm{pH}$ $\approx 3.8$ (mildly acidic condition). Because $\mathrm{f}_{\mathrm{O} 2}$ is below the related $\mathrm{SO}_{4}{ }^{2-} / \mathrm{H}_{2} \mathrm{~S}$ equilibrium, europium occurs as $\mathrm{Eu}^{2+}$ and the fluid $\mathrm{REE}_{\mathrm{CN}}$ pattern is characterized by a positive $\mathrm{Eu}$ anomaly and $(\mathrm{La} / \mathrm{Lu})_{\mathrm{CN}}>1$. Because $\mathrm{Fe}$ and $\mathrm{Al}$ in such seafloor environment will compete for $\mathrm{F}^{-}$or $\mathrm{Cl}^{-}$, REE complexation is not favored and still uncomplexed REE species will be present in the fluid.

On the other hand, lower temperatures $\left(\approx 130{ }^{\circ} \mathrm{C}\right), \mathrm{pH}$ between 6.7 and 7.3, and complexation by mono- and bicarbonates (example also in Bau, 1991), can prevent $\mathrm{Eu}^{3+}$ from being reduced to $\mathrm{Eu}^{2+}$ (as the stability of $\mathrm{Eu}^{3+}$ is extended towards lower $\mathrm{f}_{\mathrm{O} 2}$ ), resulting in no Eu anomaly and $\mathrm{La} / \mathrm{Lu}$ ratio $<1$.

Tourmaline is only stable in strong-to-weakly acid solutions (Henry and Dutrow, 1996; Palmer and Swihart, 1996). The rock must have the appropriate bulk composition to form tourmaline by metamorphism so that any boron intrinsic to the rock or introduced into the rock can react with the requisite chemical constituents to develop tourmaline. Temperature, pressure and fluid composition should be appropriate to stabilize tourmaline (Henry and Dutrow, 1996). According to Bau (1991), the REE content in metamorphic fluids can increase with increasing temperatures because of a greater availability of complexing agents like $\mathrm{F}^{-}, \mathrm{CO}_{3}^{2-}$, or $\mathrm{OH}^{-}$. If the fluid/ rock ratio is high enough, fluid-rock interaction will lead to the preferential removal of HREE from the rock, due to the predominance of $\mathrm{F}^{-}, \mathrm{CO}_{3}{ }^{2-}$, or $\mathrm{OH}^{-}$complexes in the metamorphic fluid. Because selective enrichment or removal of Eu is unlikely under these geochemical 


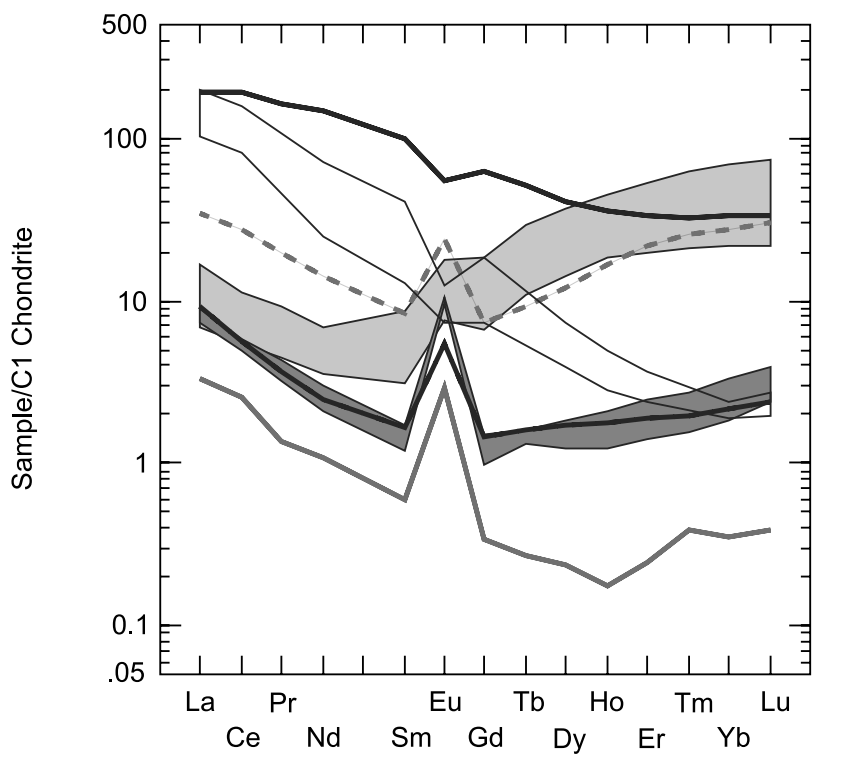

São José do Barreiro

Granite (Pereira, 2001)

SRJ-01, SRJ-03

SRJ-05, SRJ-08

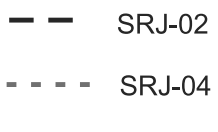

$\longrightarrow$ SJB-3A

SJB-3B

Figure 5. REE concentrations normalized to Chondrite $\mathrm{C} 1$ (Sun and McDonough, 1989).

conditions, the tourmaline that precipitates from this fluid will yield a $\mathrm{REE}_{\mathrm{CN}}$ pattern characterized by $(\mathrm{La} / \mathrm{Lu})_{\mathrm{CN}}<1$ and no Eu anomaly (our pattern 2).

Therefore, our pattern 1 and pattern 2 can be explained by the evolution of the metamorphic fluid from lower to higher temperatures, with increasing HREE content due to complexation by $\mathrm{F}^{-}, \mathrm{CO}_{3}^{2-}$, or $\mathrm{OH}^{-}$, and the change of signature, from a positive to practically no Eu anomaly. Whereas the major element composition of the SRJ tourmalines reflects the composition of the rocks from which the tourmalines are forming (Una Unit schists), the REE patterns for these tourmalines illustrate how the metamorphic fluid evolved with changing metamorphic conditions.

The tourmaline of the thin SJB-3A tourmalinite intercalated in the saibreira is the least REE-enriched, showing a positive Eu anomaly and HREE concentrations below the ICP-MS detection limits, which can be explained by high fluid/rock ratios and reducing conditions discussed above, or, better yet, considering a possible interference of magmatic-hydrothermal fluids from the São José do Barreiro Granite, such a $(\mathrm{REE})_{\mathrm{CN}}$ pattern may indicate that tourmaline derived from exsolved fluids from the magma rather than directly crystallizing from the silicate melt, once such fluids are poorer in REE relative to corresponding melt-derived tourmaline (Jolliff, Papike, Laul, 1987; Pesquera et al., 2005). On the other extreme and differing from all the other patterns, sample SJB-3B yields a slightly negative Eu anomaly and $(\mathrm{La} / \mathrm{Yb})_{\mathrm{CN}}=5.8$.

Pesquera et al. (2005) obtained very similar REE patterns to SJB-3A and SJB-3B for tourmalines from tourmalinites of the Martinamor Anticline (Salamanca, Spain). Relative to the whole rock, tourmalines from tourmalinites (which also contain quartz, plagioclase, muscovite, biotite, apatite, rutile, and zircon) exhibit: a) depletion of LFSE such as Rb, Cs and Ba that are preferentially partitioned into micas and feldspar; b) higher $\mathrm{Li}, \mathrm{Sc}, \mathrm{V}, \mathrm{Zn}$ and $\mathrm{Ga}$, but lower $\mathrm{Cr}, \mathrm{Ni}, \mathrm{Co}$, $\mathrm{Sn}, \mathrm{W}, \mathrm{Y}$, and HFSE, including $\mathrm{Zr}$, Hf, $\mathrm{Nb}$ and $\mathrm{Ta}$, the latter probably controlled by the distribution of zircon ( $\mathrm{Zr}$ and $\mathrm{Hf}$ ), rutile ( $\mathrm{Nb}$ and $\mathrm{Ta}$ ) and monazite (REE); and c) lower HREE-contents. The differences in REE patterns are explained by differential fluid/rock ratios during metasomatic processes: tourmalines with low REE abundances and positive Eu anomalies are considered to reflect deposition under relatively high fluid/rock ratios in comparison with those that have high REE abundances.

Similar to the Martinamor Anticline tourmalinites, the SJB-3B tourmaline also stands out for comparatively high HFSE concentrations, such as Th $(6.36 \mathrm{ppm})$, $\mathrm{U}$ (1.76 ppm), Hf (20 ppm), Zr (778 ppm), and total REE contents $(304.8 \mathrm{ppm})$. It also contains comparatively high $\mathrm{Sr}(258 \mathrm{ppm})$ concentrations.

The $(\mathrm{REE})_{\mathrm{CN}}$ pattern for SJB-3B resembles that of the strongly REE-fractionated São José do Barreiro Granite (Pereira, Moura, Bustamante-Junho, 2002), which may indicate contribution from magmatic-hydrothermal fluids.

It is worth mentioning that depletion of $\mathrm{Rb}, \mathrm{Cs}$ and $\mathrm{Ba}$ is observed in all samples (respectively $0.10-0.38 \mathrm{ppm}$, $0.01-0.04 \mathrm{ppm}$, and $1.65-5.80 \mathrm{ppm}$ ).

\section{Boron isotopes by SIMS}

Unfortunately the SRJ tourmalines mounted in epoxy resin could not be further analyzed for boron isotopes by SIMS, because of the interference of the resin volatilization in the analyses. Thus, only tourmalines in polished thin sections were analyzed and, as seen in Table 3 , all of the 12 boron isotope analyses yielded negative $\delta^{11} \mathrm{~B}$ values with a total range from $-12.3 \%$ o to $-13.9 \%$ o (average of $-13.1 \%$ ) for SJB-3A and $-13.9 \%$ to $-15.8 \%$ for SJB-3B (average of $-14.7 \%$ ).

The $\delta^{11} \mathrm{~B}$ values obtained in this study fall in the -15 to $-5 \%$ interval compiled by Marschall and Ludwig (2006) for tourmaline related to S-type granite magmatism, 
which is in accordance with our REE results, indicating relationship between the REE-rich fluids that originated the SBJ-3B tourmalines with the evolution of S-type São José do Barreiro Granite.

Boron has no natural redox chemistry, so fractionation between the two isotopes ${ }^{10} \mathrm{~B}$ and ${ }^{11} \mathrm{~B}$ is almost entirely controlled by their relative partitioning between trigonal, such as $\mathrm{B}(\mathrm{OH})_{3}$, and tetragonal species, such as $\mathrm{B}(\mathrm{OH})_{4}^{-}$ (Palmer and Swihart, 1996). Boron is very mobile during fluid-rock interactions and is significantly partitioned into vapor during phase separation. For example, $\mathrm{Cl}$-rich geothermal fluids are depleted in ${ }^{11} \mathrm{~B}$ due to partitioning of ${ }^{11} \mathrm{~B}$-enriched, trigonally-coordinated boron into the vapor phase (Slack, 1996).

According to Jiang et al. (2008), tourmaline can, in magmatic systems, crystallize directly from the melt or from exsolved hydrothermal fluids, and can span a large range in $\delta^{11} \mathrm{~B}$ values, from -30 to $+9 \%$. Boron isotope data can indicate whether the tourmaline crystallized directly from a melt or during late magmatic-hydrothermal activity once: a) minimal boron isotope fractionation occurs between melt and tourmaline at magmatic temperatures, so that the $\delta^{11} \mathrm{~B}$ of magmatic tourmaline should approximate that of the parental granitic magma; $b$ ) during magmatic evolution and degassing and because $\mathrm{B}(\mathrm{OH})_{3}$ is volatile, the exsolved fluids become enriched in ${ }^{11} \mathrm{~B}$, leading to an increase in the $\delta^{11} \mathrm{~B}$ of the tourmaline that precipitate from them, or a $\delta^{11} \mathrm{~B}$ decrease from core to rim of tourmaline crystallizing from the magma, as it undergoes depletion in ${ }^{11} \mathrm{~B}$ during tourmaline growth; $\mathrm{c}$ ) tourmalines forming during a single magmatic-hydrothermal stage, with boron-

Table 3. Boron isotope analyses by SIMS of tourmalines from São José do Barreiro.

\begin{tabular}{cccc}
\hline Sample & Grain & ${ }^{11} \mathrm{~B} /{ }^{10} \mathrm{~B}$ & $\delta^{11} \mathrm{~B} \%$ o \\
\hline SJB-3A & $\mathrm{t} 1$ & 3.994 & -12.31 \\
SJB-3A & $\mathrm{t} 2$ & 3.991 & -13.01 \\
SJB-3A & $\mathrm{t} 3$ & 3.988 & -13.72 \\
SJB-3A & $\mathrm{t} 4$ & 3.987 & -13.90 \\
SJB-3A & $\mathrm{t} 5$ & 3.992 & -12.79 \\
SJB-3B & $\mathrm{t} 1$ & 3.980 & -15.76 \\
SJB-3B & $\mathrm{t} 2$ & 3.988 & -13.88 \\
SJB-3B & $\mathrm{t} 3$ & 3.982 & -15.36 \\
SJB-3B & $\mathrm{t} 4$ & 3.985 & -14.51 \\
SJB-3B & $\mathrm{t} 5$ & 3.985 & -14.43 \\
SJB-3B & $\mathrm{t} 6$ & 3.987 & -14.10 \\
\hline
\end{tabular}

rich fluids being exsolved from the granitic melt, may show clear compositional differences between the cores and rims but their boron isotopic compositions remain the same (had tourmaline formed during the magmatic stage, boron isotope fractionation between the early- and laterstage tourmaline would be expected); d) involvement of a local metamorphic fluid that mixes with magmatichydrothermal fluids is suggested by slightly lower $\delta^{11} \mathrm{~B}$ values (together with increase in $\mathrm{Mg}$ contents) at rims in comparison with the cores of tourmalines; e) during both prograde and retrograde metamorphism, changes in the temperature and chemistry of circulating fluids may affect the geochemical and $\delta^{11} \mathrm{~B}$ values of the tourmaline.

The involvement of metamorphic fluids with magmatichydrothermal fluids is indicated by the slightly more negative $\delta^{11} \mathrm{~B}$ obtained for SJB-3B, which is also more $\mathrm{Mg}$ enriched, than SJB-3A (alternative (d) of Jiang et al., 2008).

\section{RUTILES}

\section{Materials and methods}

During the separation of tourmaline from sample SJB$3 \mathrm{~B}$, rutile was identified in the $100-150$ mesh fraction. Rutile prisms are either dark red or green or of both colors and they concentrate in the magnetic fraction of the Frantz separator together with tourmaline. The separates were cleaned from sulfides by chemical attack with $\mathrm{HNO}_{3}(50 \%)$ for 72 hours and quartz was removed using dense liquids.

The rutile separates were mounted in epoxy resin, polished and coated with carbon. Back-scattered electron (BSE) images and semi-quantitative (EDS) analyses were obtained at the Laboratório de Caracterização Tecnológica (São Paulo University), equipped with a LEO 440 scanning electron microscope coupled with an OXFORD Isis 300 EDS System. Quantitative (WDS) analyses were performed at the Instituto de Geociencias with the JEOL JXA-8600 microprobe operating under the following conditions: beam diameter $5 \mu \mathrm{m}$, beam current $120 \mathrm{nA}$ and acceleration voltage $20 \mathrm{kV}$.

\section{Chemical composition of retiles}

\section{BSE images and EDS and WDS analyses}

Back-scattered electron (BSE) images of rutile crystals and semi-quantitative EDS analyses obtained with the scanning electron microscope helped associate different shades of gray in the BSE images with variations in composition within single crystals. Lighter shades in the BSE images correspond to increase in $\mathrm{Fe}, \mathrm{Sn}, \mathrm{W}$ and $\mathrm{Nb}$ contents, as indicated in Figure 6 by arrows. 

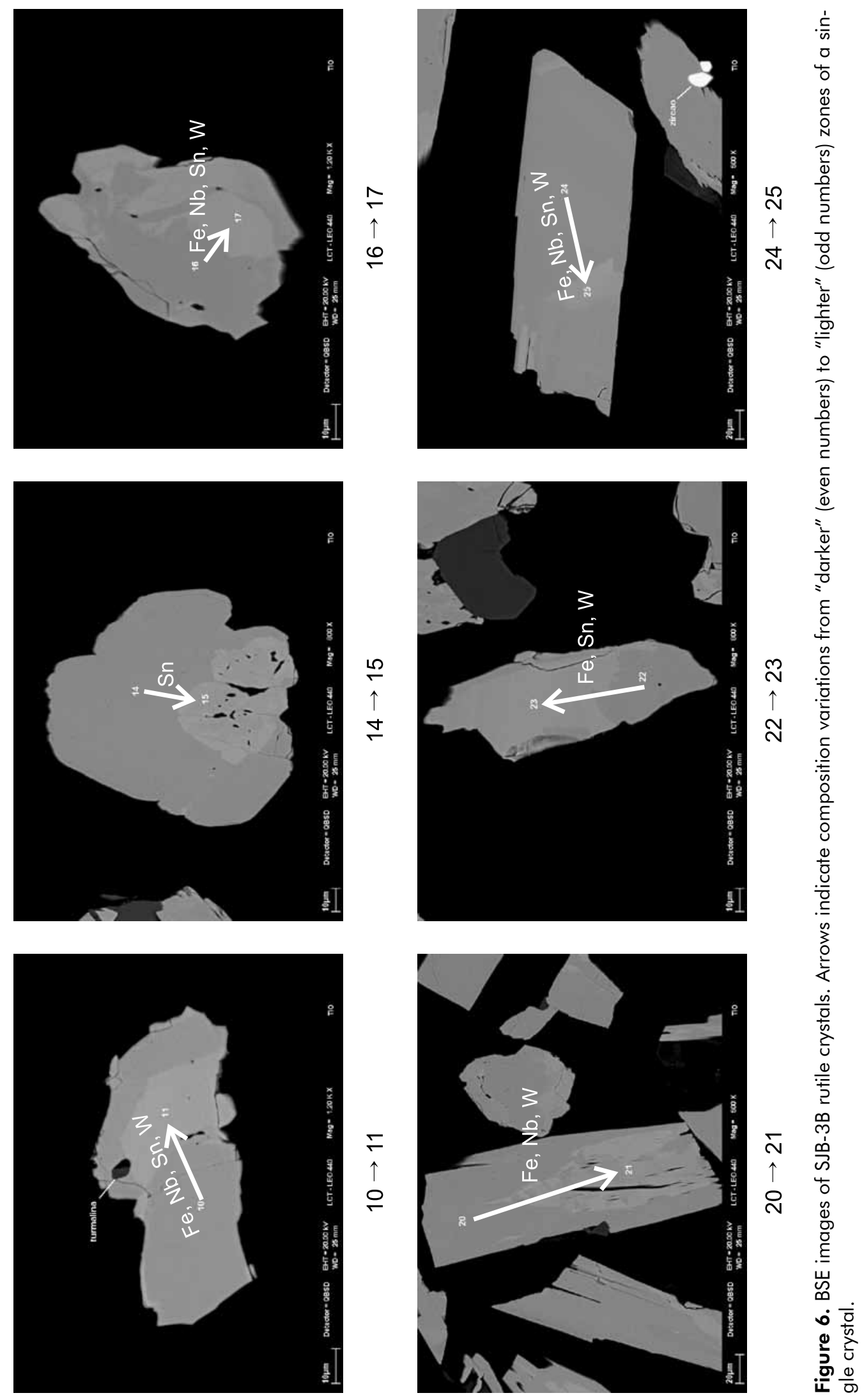
Quantitative WDS analyses were carried out in red and green parts of rutile crystals mounted in epoxi resin and the results are presented in Table 4.

Average $\mathrm{TiO}_{2}$ content in red rutiles is 96 wt.\% ( $\pm 1 \mathrm{wt} . \%$ ), whereas in green rutiles it is slightly lower, 95 wt.\% ( \pm 2 wt.\%). Cr contents in green rutiles are restricted to the $443-1007 \mathrm{ppm}$ interval, whereas in red rutiles they vary between 2392 and $6497 \mathrm{ppm}$. On the other hand, $\mathrm{Nb}$ contents in red rutiles fall in the $3910-5203 \mathrm{ppm}$ interval, whereas they vary from 2000 to $7500 \mathrm{ppm}$ in green rutiles (Figure 7A). The contents of $\mathrm{Si}$ (Figure 7C); $\mathrm{Al}$ (Figure 7D); Fe (Figure 7E), and Sn (Figure 7G) are higher in green than in red rutiles.

As mentioned before, rutile chemistry and thermometry has been used as a guide to provenance for a variety of geological settings. For example, Zack, Moraes and Kronz (2004b) observed an important correlation between $\mathrm{Zr}$ content in rutile and metamorphic peak and devised a

Table 4. Microprobe (WDS) analyses of SJB-3B rutile separates. Labels SJB-3B-V and SJB-3B-P indicate green and red rutile respectively. Ti contents in wt.\% and trace elements contents in ppm.

\begin{tabular}{|c|c|c|c|c|c|c|c|c|c|}
\hline Sample & Ti wt. $\%$ & $\mathrm{Si}$ & $\mathrm{Cr}$ & $\mathrm{Al}$ & $\mathrm{Nb}$ & $\mathrm{Fe}$ & V & $\mathrm{Zr}$ & Sn \\
\hline SJB-3B-V02 & 58.44 & 174 & 968 & 368 & 2192 & 1941 & 1391 & 113 & 11201 \\
\hline SJB-3B-V03 & 57.29 & 0 & 769 & 765 & 6758 & 7023 & 1821 & 112 & 15368 \\
\hline SJB-3B-V04 & 58.34 & 418 & 774 & 435 & 2537 & 1871 & 1328 & 226 & 11933 \\
\hline SJB-3B-V05a & 57.55 & 0 & 449 & 733 & 5505 & 6549 & 1446 & 113 & 14654 \\
\hline SJB-3B-V05b & 58.43 & 35 & 1228 & 268 & 6238 & 3958 & 1710 & 454 & 3985 \\
\hline SJB-3B-V06 & 58.14 & 70 & 902 & 468 & 3455 & 2492 & 1642 & 113 & 12801 \\
\hline SJB-3B-V07 & 58.03 & 383 & 1225 & 769 & 2995 & 2215 & 1895 & 113 & 13392 \\
\hline SJB-3B-V08 & 57.68 & 69 & 449 & 366 & 4128 & 3791 & 1320 & 225 & 17876 \\
\hline SJB-3B-V09 & 56.75 & 69 & 446 & 496 & 4897 & 4724 & 1436 & 112 & 28086 \\
\hline SJB-3B-V10 & 58.24 & 174 & 322 & 469 & 2996 & 2840 & 1706 & 113 & 12074 \\
\hline SJB-3B-V12-1 & 56.95 & 0 & 640 & 1062 & 6629 & 9480 & 1943 & 224 & 16940 \\
\hline SJB-3B-V12-2 & 56.93 & 0 & 576 & 896 & 6513 & 10165 & 1942 & 224 & 16790 \\
\hline SJB-3B-V13 & 56.54 & 69 & 956 & 694 & 5692 & 6295 & 1810 & 112 & 26909 \\
\hline SJB-3B-V14 & 58.48 & 35 & 970 & 403 & 4158 & 3194 & 1900 & 227 & 6493 \\
\hline SJB-3B-V15 & 58.08 & 174 & 838 & 368 & 4720 & 2976 & 1389 & 339 & 11915 \\
\hline SJB-3B-V16 & 57.38 & 35 & 320 & 599 & 5152 & 5988 & 1507 & 112 & 18141 \\
\hline SJB-3B-V21 & 56.93 & 35 & 767 & 962 & 6740 & 9889 & 1629 & 112 & 17079 \\
\hline SJB-3B-V22 & 58.1 & 70 & 644 & 502 & 4030 & 3183 & 1704 & 113 & 12210 \\
\hline SJB-3B-V23-1 & 58.42 & 139 & 1162 & 435 & 2538 & 1941 & 1328 & 227 & 10759 \\
\hline SJB-3B-V25 & 57.09 & 0 & 1089 & 897 & 7208 & 7359 & 1819 & 112 & 16520 \\
\hline SJB-3B-P01 & 58.36 & 35 & 2908 & 302 & 4156 & 2637 & 1773 & 453 & 6491 \\
\hline SJB-3B-P02 & 58.56 & 0 & 2135 & 302 & 4046 & 2779 & 1775 & 341 & 4874 \\
\hline SJB-3B-P03 & 58.38 & 35 & 4591 & 201 & 4274 & 1597 & 1710 & 340 & 5609 \\
\hline SJB-3B-P04 & 58.27 & 70 & 1614 & 335 & 5306 & 2982 & 1771 & n.d. & 7959 \\
\hline SJB-3B-P05 & 58.31 & 0 & 3813 & 402 & 4619 & 3609 & 1836 & 227 & 4722 \\
\hline SJB-3B-P06a & 58.11 & 35 & 4840 & 268 & 4497 & 3119 & 1770 & 113 & 7072 \\
\hline SJB-3B-P06b & 58.43 & 105 & 2458 & 268 & 4853 & 2987 & 1837 & 454 & 4725 \\
\hline SJB-3B-P07 & 58.1 & 0 & 7300 & 302 & 5541 & 1457 & 1646 & 453 & 4720 \\
\hline SJB-3B-P08 & 58.45 & 35 & 1292 & 369 & 3117 & 3539 & 1772 & 113 & 7670 \\
\hline SJB-3B-P11 & 58.27 & 0 & 4588 & 201 & 5772 & 2221 & 1456 & 453 & 5015 \\
\hline SJB-3B-P12 & 58.37 & 0 & 5562 & 201 & 4160 & 1459 & 1711 & 454 & 4725 \\
\hline SJB-3B-P13 & 58.41 & 0 & 5886 & 168 & 4392 & 1181 & 1457 & 227 & 4578 \\
\hline SJB-3B-P14 & 58.18 & 0 & 8660 & 134 & 4041 & 763 & 1583 & 227 & 5164 \\
\hline SJB-3B-P15 & 58.26 & 0 & 3422 & 268 & 3577 & 3121 & 1835 & 113 & 7666 \\
\hline
\end{tabular}



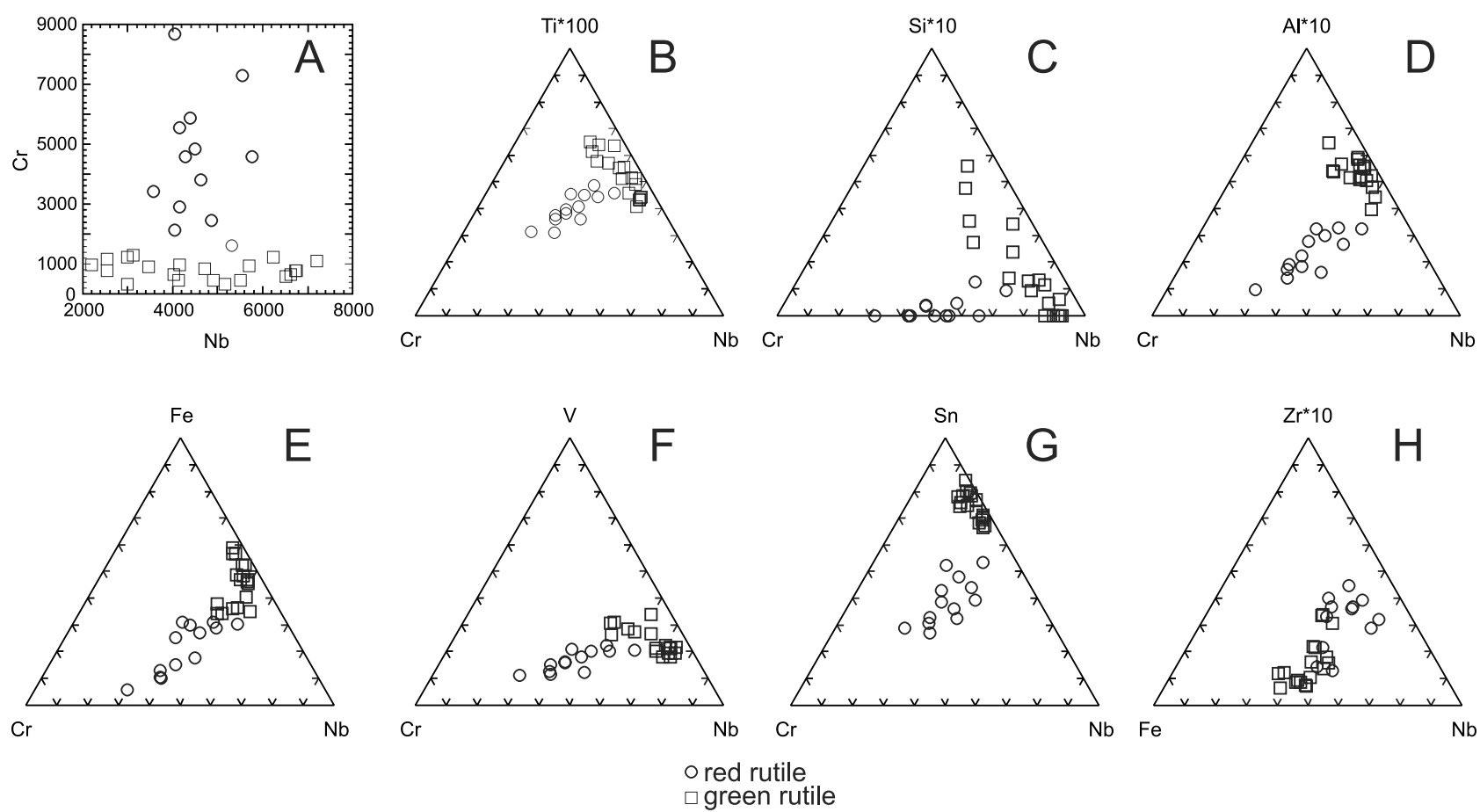

Figure 7. Chemical variation diagrams for red and green rutiles from sample SJB-3B.

geothermometer with possible applications covering the fields of ultrahigh temperature granulites, sedimentary provenance studies and metamorphic field gradients. Watson, Wark and Thomas (2006) presented a revised Zr-in-rutile thermometer based on experimental data and natural rutiles from metamorphic rocks.

Fernández, Schalamuk and Omenetto (2005), based on $\mathrm{Fe}, \mathrm{Sn}, \mathrm{Nb}, \mathrm{Ta}$ and $\mathrm{W}$ contents in rutile from greisenized host rock and vein-related greisen of the Sn-W Mazan District (Argentina), distinguish two different greisen-forming conditions. The authors propose that the rutile present in the vein-related greisen fundamentally formed from Ti-bearing hydrothermal solutions (at high fluid/rock ratios), whereas the rutile of the greisenized host rock formed at the expense of Ti liberated during the destruction of rock minerals (at low fluid/rock ratios). At high fluid/rock ratios, cassiterite and wolframite deposited together with rutile.

According to Force (1980), hydrothermally or metasomatically altered rocks commonly contain rutile (porphyry copper deposits, wallrocks of metamorphosed massive sulfide deposits, metamorphosed ultramafic rocks), and, although rare in granitic pegmatites because of the low $\mathrm{TiO}_{2}$ contents of residual melts, it is a common phase in the country rocks. Therefore, both medium- to high-grade metamorphism and hydrothermal activity can mobilize Ti from country rocks to produce rutile. It is possible that the red rutile at predominant high rock/ fluid ratios, whereas green rutile formed at low rock/fluid ratios, a possible source of magmatic-hydrothermal fluids being the São José do Barreiro Granite. The Ti-rich zones in coarse-grained tourmaline (Figure $2 \mathrm{C}$ and Figure $7 \mathrm{H}$ ) may correspond to changes in fluid composition. Other minerals, such as zircon, monazite and scheelite (identified in BSE images of rutile separates), may have precipitated under these conditions.

As further mechanism of Sn and W incorporation by rutile, Müller and Halls (2005) suggested the contribution from relatively oxidizing formation waters reacting with the magmatic residue, based on the high $\mathrm{Fe}(\mathrm{Sn}, \mathrm{W})$ in the final outer growth zones of rutile and tourmaline of the tourmaline breccia at Wheal Remfry (SW England). Considering the geologic setting of the study area, it is possible that meteoric waters also played a role in rutile and tourmaline formation, but the data obtained is not enough to attest the involvement of fluids other than metamorphic and (post-) magmatic.

\section{CONCLUSIONS}

Tourmaline and rutile geochemistry helped distinguish two main phases of tourmaline formation in tourmalinerich layers intercalated with the Embu Complex aluminous 
schists and with quartzite (saibreiras) of the São José do Barreiro-Formoso region.

The tourmalines of the schist-hosted tourmaline layers are characterized by relatively low $\mathrm{MgO}, \mathrm{Na}_{2} \mathrm{O}$ and $\mathrm{CaO}$ contents and high $\mathrm{Al}_{2} \mathrm{O}_{3}$ and $\mathrm{FeO}$ contents. Two $(\mathrm{REE})_{\mathrm{CN}}$ patterns were defined for these tourmalines, one represented by $(\mathrm{La} / \mathrm{Yb})_{\mathrm{CN}}$ from 2.7 to 4.3 and positive $\mathrm{Eu}$ anomalies, and the other by $(\mathrm{La} / \mathrm{Yb})_{\mathrm{CN}}$ from 0.2 to 0.3 and practically no $\mathrm{Eu}$ anomalies. The variations in major-element contents reflect the composition of the metamorphic rock in which the tourmaline is crystallizing, whereas the $(\mathrm{REE})_{\mathrm{CN}}$ patterns indicate the evolution of the metamorphic fluids with increasing temperatures.

The tourmaline of the tourmalinite layer intercalated in quartzite is characterized by relatively high $\mathrm{Al}_{2} \mathrm{O}_{3}, \mathrm{FeO}$ and $\mathrm{Na}_{2} \mathrm{O}$ contents and very low total REE contents. Its $(\mathrm{REE})_{\mathrm{CN}}$ pattern is characterized by a positive Eu anomaly. $\delta^{11} \mathrm{~B}$ values for this tourmaline fall in the -12.3 and $-13.9 \%$ interval. On the other hand, the tourmaline of a massive tourmalinite has the highest $\mathrm{MgO}, \mathrm{CaO}, \mathrm{F}, \mathrm{Th}, \mathrm{U}, \mathrm{Hf}, \mathrm{Zr}$, $\mathrm{Y}, \mathrm{Sr}$ and total REE contents and the lowest $\mathrm{Al}_{2} \mathrm{O}_{3}$ and $\mathrm{FeO}$ contents. Differing from all other $(\mathrm{REE})_{\mathrm{CN}}$ patterns, the one that characterizes this tourmaline is LREE-enriched $\left[(\mathrm{La} / \mathrm{Yb})_{\mathrm{CN}}=5.8\right]$ and shows a slightly negative $\mathrm{Eu}$ anomaly. $\delta^{11} \mathrm{~B}$ values in the -13.9 and $-15.8 \%$ interval indicate an S-type granite filiation.

The green rutile of the massive tourmalinite is enriched in $\mathrm{Nb}, \mathrm{Al}, \mathrm{Fe}$ and $\mathrm{Sn}$ when compared to the $\mathrm{Cr}$-rich red rutile. The differences in composition observed in the tourmaline and rutile of the massive tourmalinite indicate the involvement of magmatic-hydrothermal fluids from the S-type São José do Barreiro Granite with metamorphic fluids from which tourmaline crystallized.

The formation of zircon, scheelite, and monazite in the massive tourmalinite must be related to this second phase of tourmaline crystallization. Fluid inclusion studies may attest for both change in fluid composition and metal ( $\mathrm{Sn}$, $\mathrm{W}$, and $\mathrm{Nb}$ ) deposition.

\section{ACKNOWLEDGMENTS}

The authors wish to thank FAPESP (Processes 2005/56651-3 and 2007/53895-4) for financial support for this project. G. M. Garda and P. Beljavskis are greatly indebted to Ronaldo M. Pereira for the SRJ tourmaline separates, to Marcos S. Mansueto for his assistance during microprobe analyses, to Margaret S. Navarro for trace element analyses by ICP-MS, and to Dr. Robert B. Trumbull from GFZ Potsdam, for monitoring sample preparation and SIMS analyses and for the extremely critical review of the first drafts of this manuscript.
G. M. Garda also wishes to thank FAPESP (Process 2010/50768-4) for the opportunity to present a poster on this paper in the IMA2010 Meeting (Bonds and Bridges: Mineral Sciences and Their Applications) in Budapest (Hungary).

\section{REFERENCES}

BAU, M. Rare-earth element mobility during hydrothermal and metamorphic fluid-rock interaction and the significance of the oxidation state of europium. Chemical Geology, v. 93, p. 219-230, 1991.

BORTNIKOV, N. S.; GORELIKOVA, N. V.; KOROSTELEV, P. G.; GONEVCHUK, V. G. Rare earth elements in tourmaline and chlorite from tin-bearing assemblages: Factors controlling fractionation of REE in hydrothermal systems. Geology of ore deposits, v. 50, n. 6 , p. $445-461,2008$.

CATANZARO, E. J.; CHAMPION, C. E.; GARNER, E. L.; MALINENKO, G.; SAPPENFIELD, K. M.; SHIELDS, W. R. Boric acid: isotopic and assay standard reference materials. Washington, D. C.: US National Bureau Standards, Special Publication 260-17, 70 p. 1970.

DYAR, M. D.; WIEDENBECK, M.; ROBERTSON, D.; CROSS, L. R.; DELANEY, J. S.; FERGUSON, K.; FRANCIS, C. A.; GREW, E. S.; GUIDOTTI, C. V.; HERVIG, R. L.; HUGHES, J. M.; HUSLER, J.; LEEMAN, W.; McGUIRE, A. V.; RHEDE, D.; ROTHE, H.; PAUL, R. L.; RICHARDS, I.; YATES, M. Reference minerals for microanalysis of light elements. Geostandard Newsletter, v. 25, p. 441-463, 2001.

FERNÁNDEZ, R. R.; SCHALAMUK, I. B. A.; OMENETTO, P. Composición del rutilo como indicador de las condiciones de formación del greisen del distrito Mazán (Sn-W), provincia de La Rioja. Revista de la Asociación Geológica Argentina, v. 60, p. 259-267, 2005.

FORCE, E. R. The provenance of rutile. Journal of Sedimentary Petrology, v. 50, p. 485-488. 1980.

GARDA, G. M.; TRUMBULL, R. B.; BELJAVSKIS, P.; WIEDENBECK, M. Boron isotope composition of tourmalinite and vein tourmalines associated with gold mineralization, Serra do Itaberaba Group, central Ribeira Belt, SE Brazil. Chemical Geology, v. 264, p. 207-220. 2009.

HASUI, Y.; OLIVEIRA, M. A. F. Província Mantiqueira - setor central. In: ALMEIDA, F. F. M.; HASUI, Y. 
(Coord.). O Pré-Cambriano do Brasil. São Paulo: Edgar Blucher, 1984. p. 308-344.

HENRY, D. J.; DUTROW, B. L. Metamorphic tourmaline and its petrogenetic applications. In: GREW, E. S.; ANOVITZ, L. M. (Ed.). Boron: mineralogy, petrology and geochemistry. Chantilly, Va.: Mineralogical Society of America, 1996. p. 503-557. (Reviews in Mineralogy, v. 33).

HENRY, D. J.; GUIDOTTI, C. V. Tourmaline as a petrogenetic indicator mineral: an example from the staurolite-grade metapelites of NW Maine. American Mineralogist, v. 70, p. 1-15, 1985.

JIANG, S. Y.; RADVANEC, M.; NAKAMURA, E.; PALMER, M.; KOBAYASHI, K.; ZHAO, H. X.; ZHAO, K. D. Chemical and boron isotopic variations of tourmaline in the Hnilec granite-related hydrothermal system, Slovakia: constraints on magmatic and metamorphic fluid evolution. Lithos, v. 106, p. 1-11, 2008.

JOLLIFF, B. L.; PAPIKE, J. J.; LAUL, J. C. Mineral recorders of pegmatite internal evolution: REE contents of tourmaline from the Bob Ingersoll pegmatite, South Dakota. Geochimica et Cosmochimica Acta, v. 51, p. 2225-2232, 1987.

MARSCHALL, H. R.; LUDWIG, T. Re-examination of the boron isotopic composition of tourmaline from the Lavicky granite, Czech Republic, by secondary ion mass spectrometry: back to normal. Geochemical Journal, v. 40, p. 631-638, 2006.

MEINHOLD, G.; ANDERS, B.; KOSTOPOULOS, D.; REISCHMANN, T. Rutile chemistry and thermometry as provenance indicator: an example from Chios Island, Greece. Sedimentary Geology, v. 203, p. 98-111. 2008.

MORTON, A.; CHENERY, S. Detrital rutile geochemistry and thermometry as guides to provenance of JurassicPaleocene sandstones of the Norwegian Sea. Journal of Sedimentary Research, v. 79, p. 540-553, 2009.

MÜLLER, A.; HALLS, C. Rutile - the tin-tungsten host in the intrusive tourmaline breccia at Wheal Remfry, SW England. In: MAO, J.; BIERLEIN, F. P. Mineral deposit research: Berlin-Heidelberg: Springer, 2005. p. 441-444. (Meeting the global challenge).

NAVARRO, M. S. A implantação de rotina e seu refinamento para a determinação de elementos terras raras em materiais geológicos por ICP-OES e ICP-MS: aplicação ao caso dos granitóides de Piedade-Ibiúna (SP) e Cunhaporanga (PR). 2004. 132 f. Dissertação (Mestrado) - Instituto de Geociências, Universidade de São Paulo, São Paulo, 2004.

PALMER, M. R.; SLACK, J. F. Boron isotopic composition of tourmaline from massive sulfide deposits and tourmalinites. Contributions to Mineralogy and Petrology, v. 103, p. 434-451, 1989.

PALMER, M. R.; SWIHART, G. H. Boron isotope geochemistry: An overview. In: GREW, E. S.; ANOVITZ, L. M.(Ed.). Boron: mineralogy, petrology and geochemistry. Chantilly, Va: Mineralogical Society of America, 1996. p. 709-744. (Reviews in Mineralogy, v. 33).

PEREIRA, R. M. Caracterização geocronológica, geoquímica, geofísica e metalogênica de alguns plutonitos graníticos da região do médio rio Paraíba do Sul e alto Rio Grande, segmento central da Faixa Ribeira. 2001. $213 \mathrm{f}$. Tese (Doutorado) - Universidade Federal do Rio de Janeiro, Rio de Janeiro, 2001.

PEREIRA, R. M.; ÁVILA, C. A.; MOURA, C. A.V. Geologia da região entre Resende e São José do Barreiro e idade ${ }^{207} \mathrm{~Pb} / 206 \mathrm{~Pb}$ do Granito do Funil, segmento central da Faixa Ribeira (RJ-SP), Brasil. Geociências, Rio Claro, v. 20, p. $37-48,2001$.

PEREIRA, R. M.; MOURA, C. A. V.; BUSTAMANTEJUNHO, M. C. Single zircon Pb-evaporation age of some granitic plutons in the central part of the Ribeira Belt, southeastern Brazil. Revista Brasileira de Geociencias, v. 32, p. 327-334, 2002.

PEREIRA, R. M.; ÁVILA, C. A.; NEUMANN, R. Prospecção para cassiterita na região entre Cachoeira Paulista (SP) e Resende (RJ): potencialidade em estanho dos granitos do Funil e São José do Barreiro, segmento central da Faixa Ribeira. Geociências, v. 22, p. 107-119, 2003.

PESQUERA, A.; TORRES-RUIZ, J.; GIL-CRESPO, P. P.; JIANG, S. Y. Petrographic, chemical and B-isotopic insights into the origin of tourmaline-rich rocks and boron recycling in the Martinamor Antiform (Central Iberian Zone, Salamanca, Spain). Journal of Petrology, v. 46, p. 1013-1044, 2005.

ROIG, H. L.; DANTAS, E. L.; MENEZES, P. L. Nd isotopes from the Ribeira Belt in the Rio Paraíba do Sul region, SE Brazil: significance for its Neoproterozoic evolution. Journal of the Virtual Explorer Electronic Edition, v. 17, Paper 5, p. 1-19, 2004. 
SLACK, J. F. Tourmaline associations with hydrothermal ore deposits. In: GREW, E. S. ; ANOVITZ, L. M. (Ed.). Boron: mineralogy, petrology and geochemistry. Chantilly, Va: Mineralogical Society of America, 1996. p. 559-644. (Reviews in Mineralogy, v. 33).

SUN, S.; McDONOUGH, W. F. Chemical and isotopic systematics of oceanic basalts: implications for mantle composition and processes. In: SAUNDER, A. D.; NORRY, M. J. (Ed.). Magmatism in the ocean basins. Oxford: Blackwell, 1989. p. 313-345. ( Geological Society Special Publication, 42 ).

UFRJ/CPRM. Geologia da Folha Volta Redonda SF.23$Z-A-V$ escala 1:100.000. Rio de Janeiro, Universidade Federal do Rio de Janeiro/Serviço Geológico do Brasil, 2007. $148 \mathrm{p}$.

WATSON, E. B.; WARK, D. A.; THOMAS, J. B. Crystallization thermometers for zircon and rutile. Contributions to Mineralogy and Petrology, v. 151, p. 413-433, 2006.

ZACK, T.; VON EYNATTEN, H.; KRONZ, A. Rutile geochemistry and its potential use in quantitative provenance studies. Sedimentary Geology, v. 171, p. 37-58, 2004a.

ZACK, T.; MORAES, R.; KRONZ, A. Temperature dependence of $\mathrm{Zr}$ in rutile: empirical calibration of a rutile thermometer. Contributions to Mineralogy and Petrology, v. 148, p. 471-488, 2004 b. 
